\title{
مترجمو ألف ليلة وليلة
}

\section{بقلم : خورخى لويس بورخيس}

\section{خرجمة وتقديم الدكتور / حامد أبو احمد}

خورخى لويس بورخيس كاتب أرجنتينى بتعدى عمره الآن الثمانين

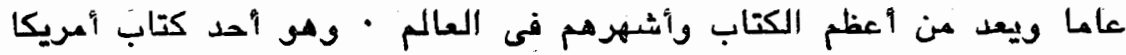

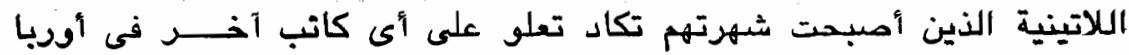

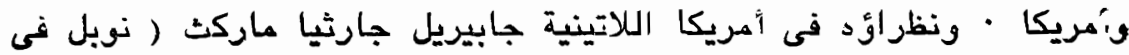

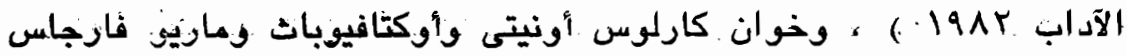

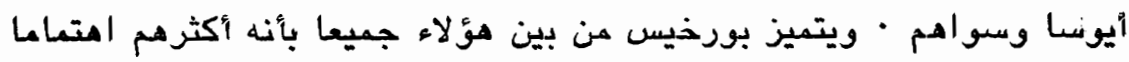

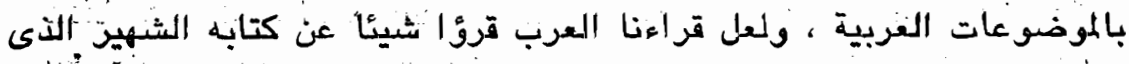

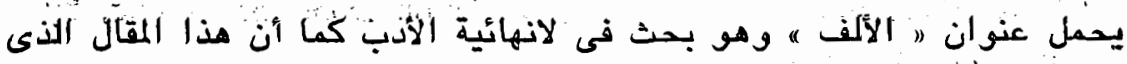

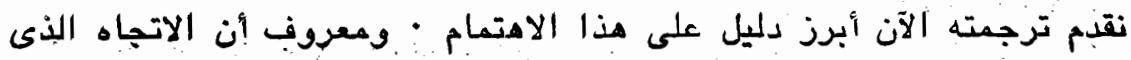

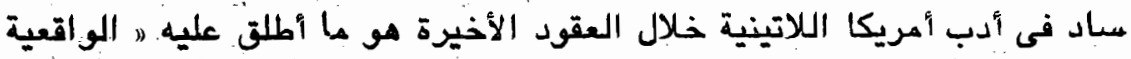

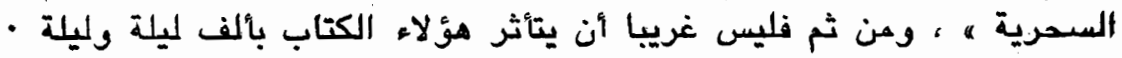

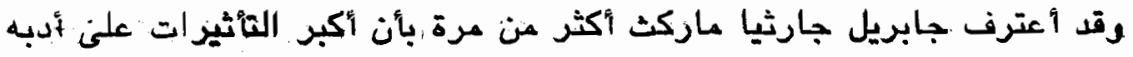

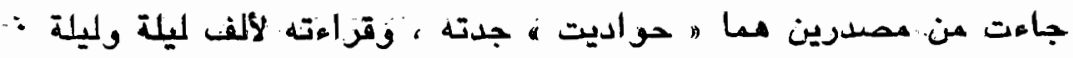

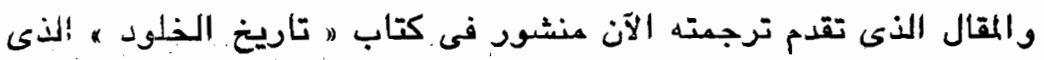

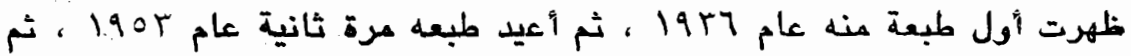

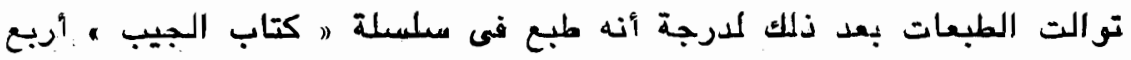

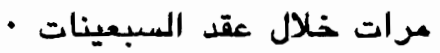

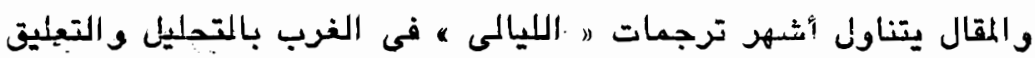

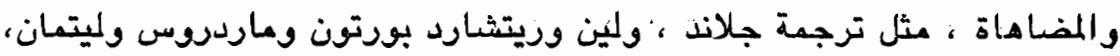

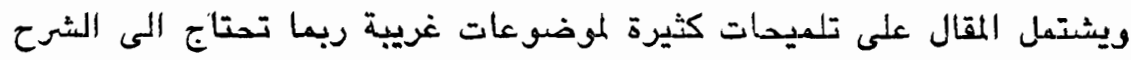

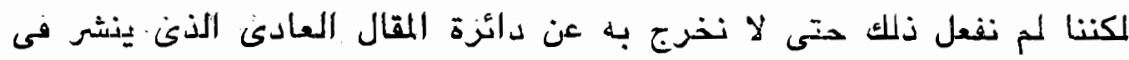

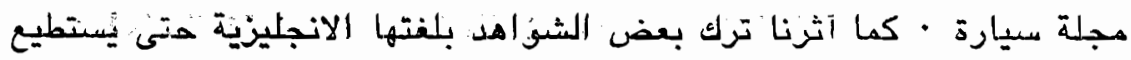

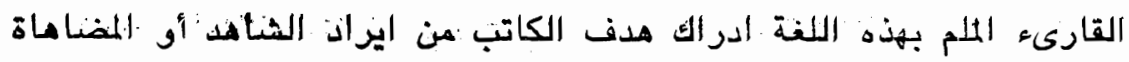

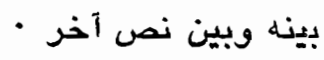




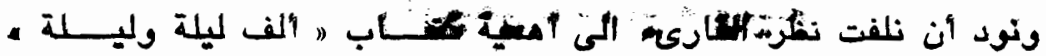

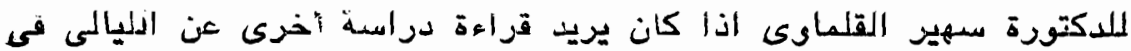

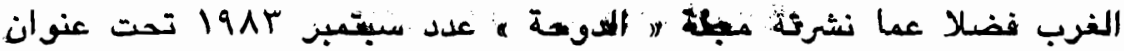

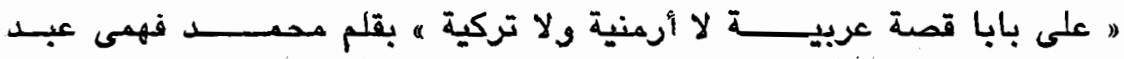

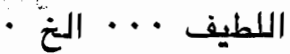

وأخيرا اليك قائمة بالنسيخ التى قام خورخى لويس بورخيس بالمضاهات

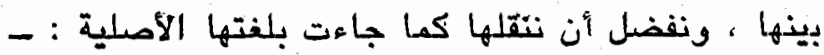

- Les Mille et une Niuts, contes arabes tradaits par Galand. Paris, s.d.

- The Thousand and One Nights, Commonly Called the Arabian Nights' Entertainments. A New translation from the Arabic, by E.W. Lane. London, 1839.

-- The Book of the Thousand Nights and a Night. A ptaif and literal translation by Richard F. Burton. London (?), n.d. VoIs. VI, VII, VIrI.

- The Arabian Nights. A Complete (sic) and urabritged seleetion - from the famous literal translation of R.F. Burton New Yrok, 1932.

- Le Livre des Mille Nuits et Une Nuit. Traduction littérale et complète du Texte arabe, par le Dr. J.C. Mardus. Paris, 1906.

- Tausend und eine Nacht. Aus dem Arabischen übertragen von Max Henning-Leipzig, 1897.

- Die Erzäblungen aus der Tausendundein Nächten. Nachdem arabischen Urtext der Valcuttaer Ausgabe vom Jahre 1839 übertragen von Enno Littmann. Leipzig, 1928.

وفيما يلى نص منّال خورخى لويس بوخيس ( وقد بذلنا غاية الجهد

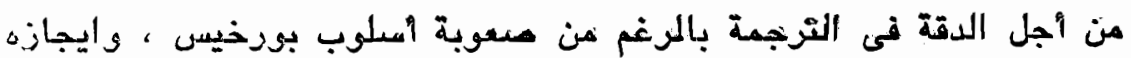

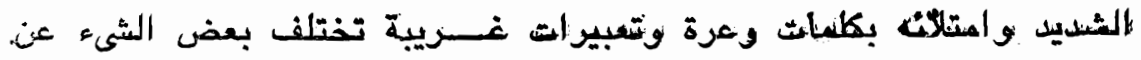

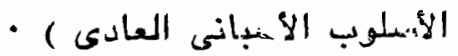




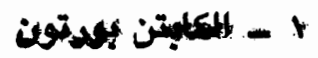

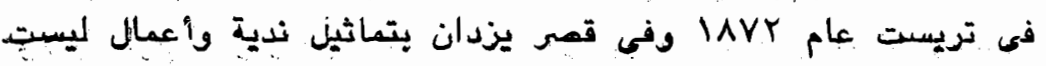

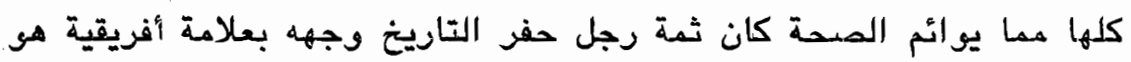

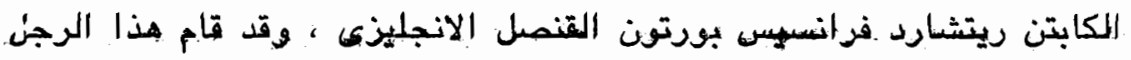

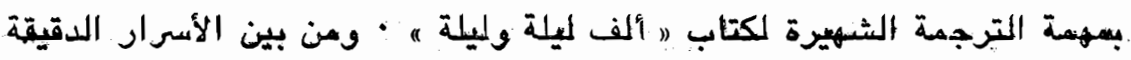

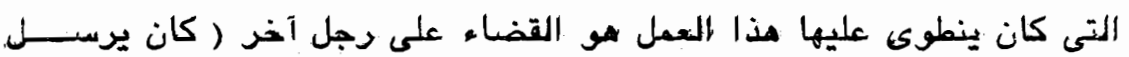

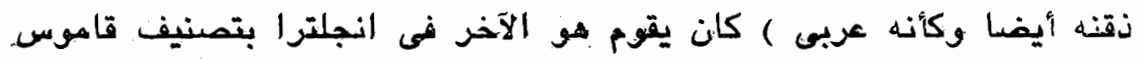

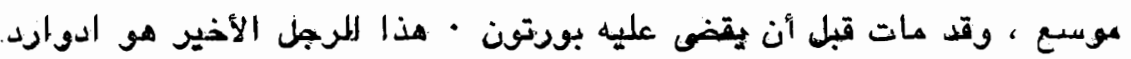

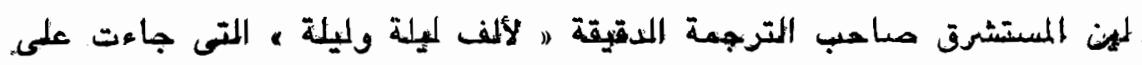

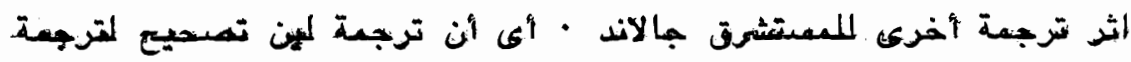

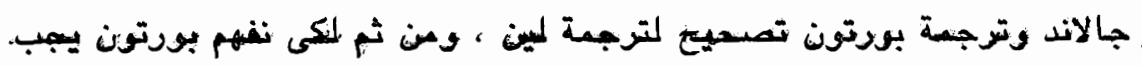

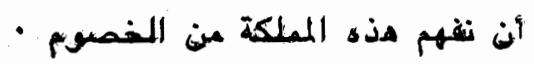

وأبدأ بالمؤسس • فمن المصروف أن جان أنطوان مهلاند كان مسبـمربا فرنسيا • ومو اللذى أحضر من أسطنبول مجموعة كبيزة من العملات النقدينة.

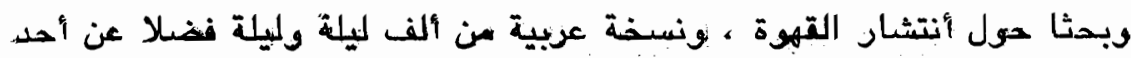

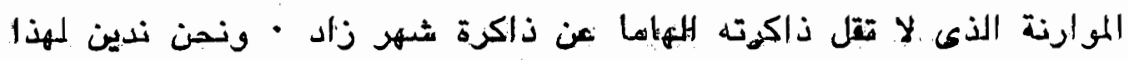

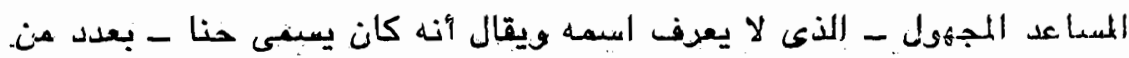

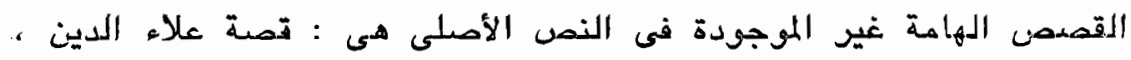

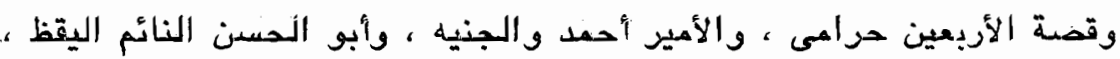

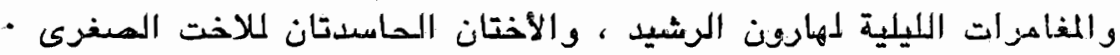

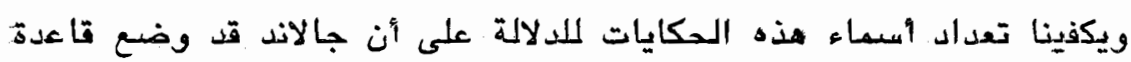

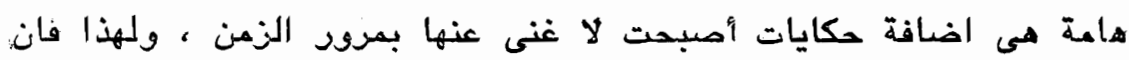

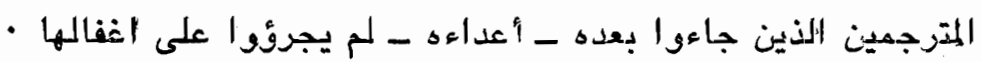

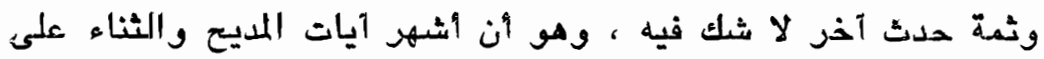

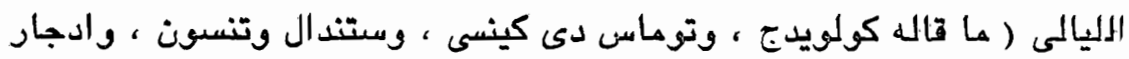

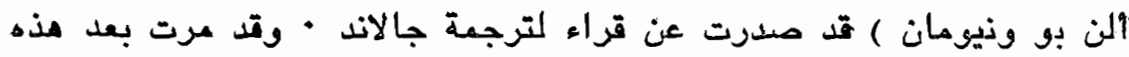

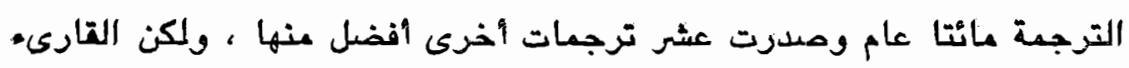

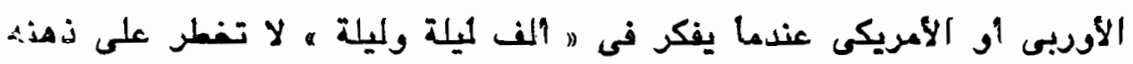




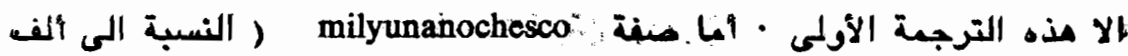

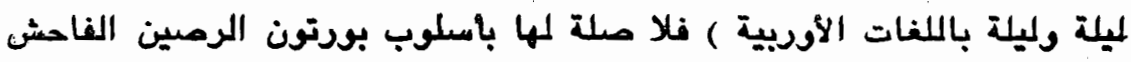

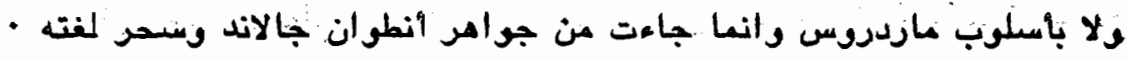

وباختصار فان ترجمة جالاند تعد أسوا الترجعات جميعـــ وأكثرمها

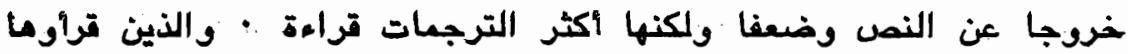

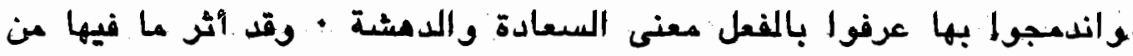

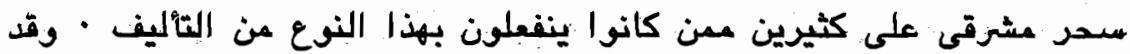

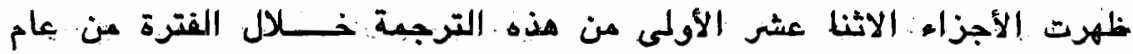

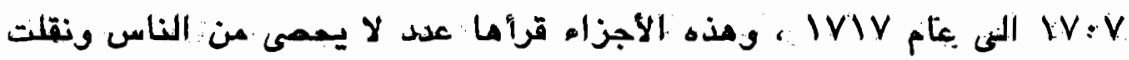

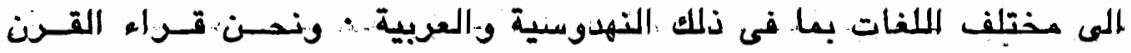

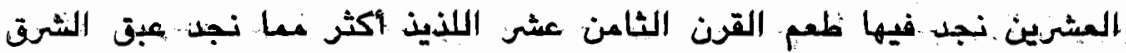

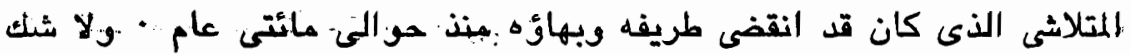

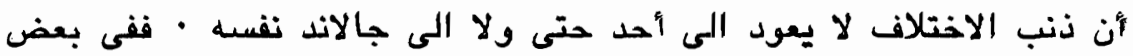

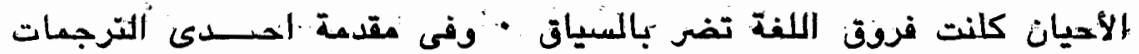

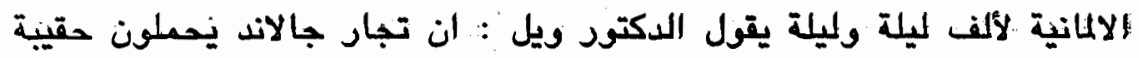

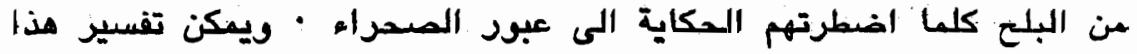

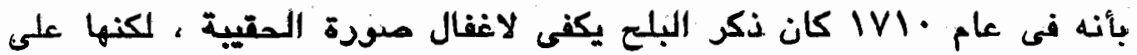

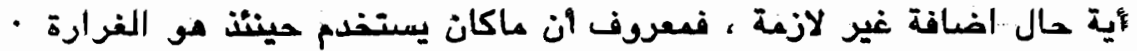

وثمة انتقادات أخرى · ففى الاطراء الذى يتمدر " القطع المختارة ه

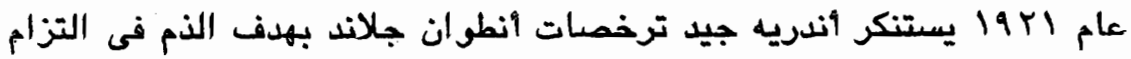

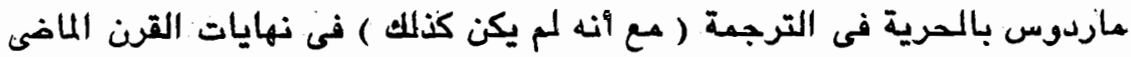

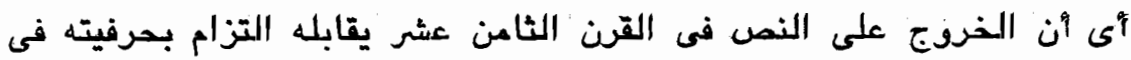

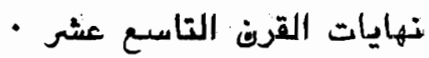

وتدفظات جالاند معروفة ، فهى متصلة بالديكون لا بالأخلاقيات وأنا

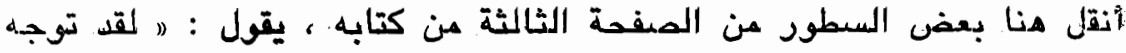

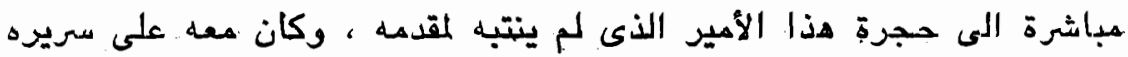

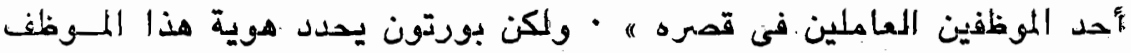




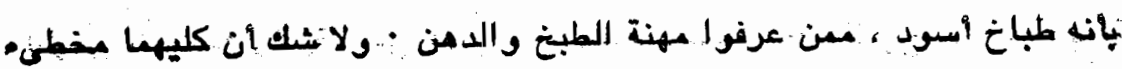

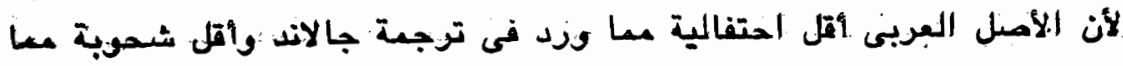

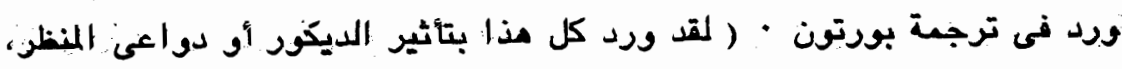

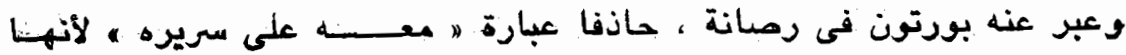
• قاسية

وبعد موت أنطوان جالاند بتسعين عاما ولد هترجم أخر :لألف ليلة وليلة

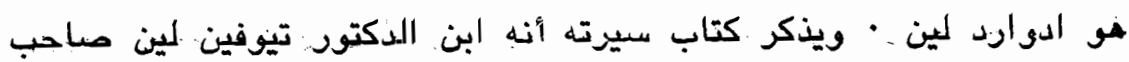

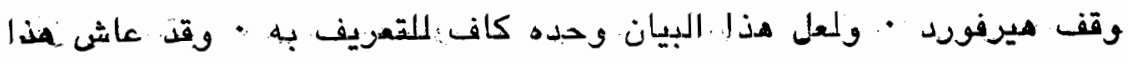

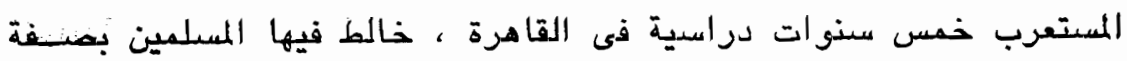

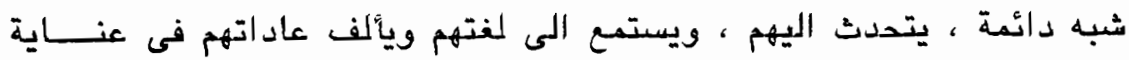

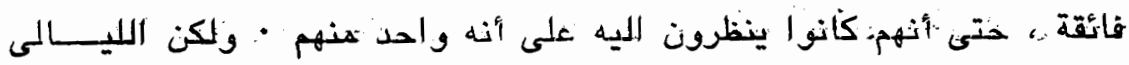

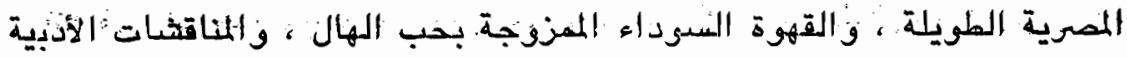

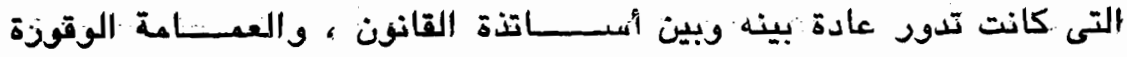

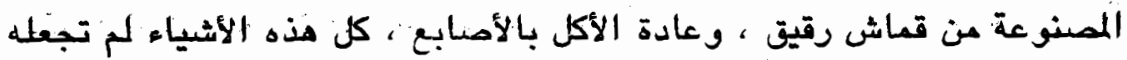

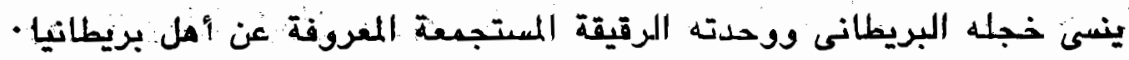

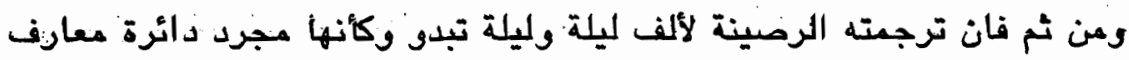

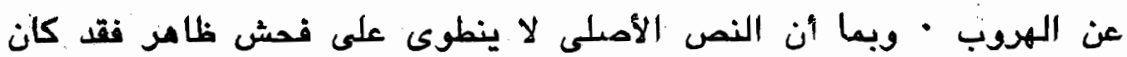

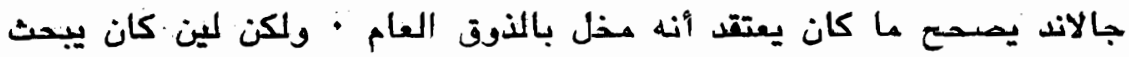

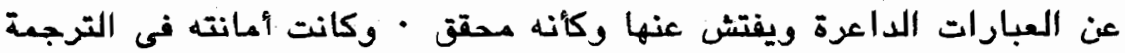

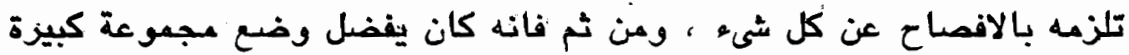

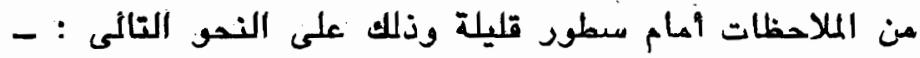

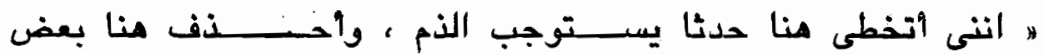

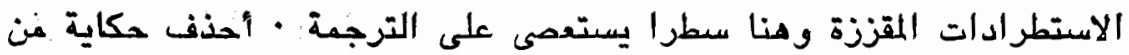

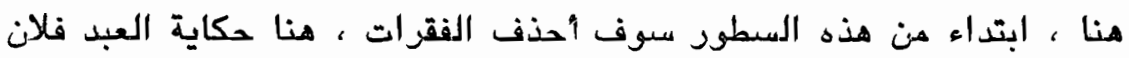

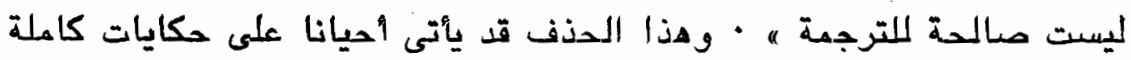

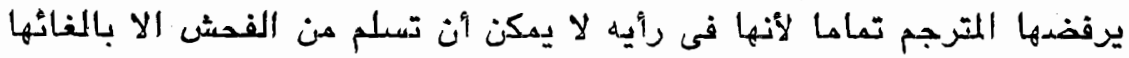

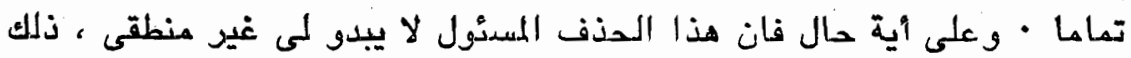

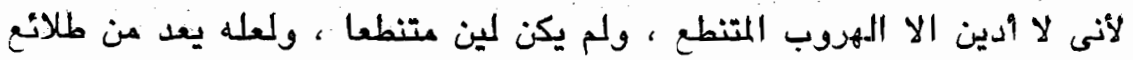




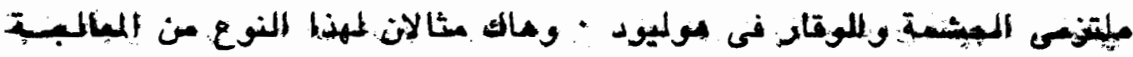

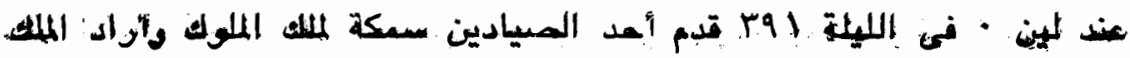

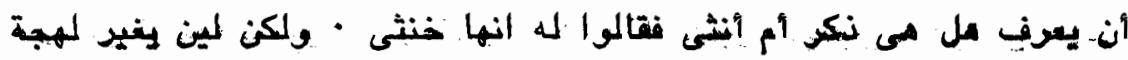

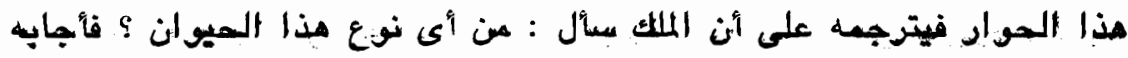

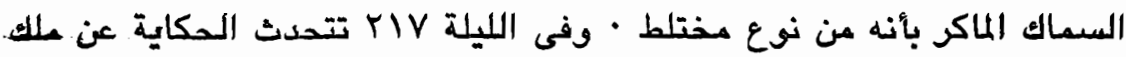

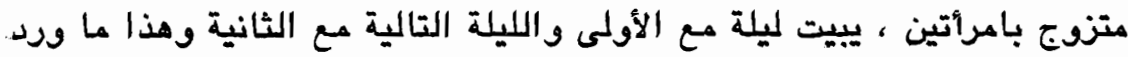

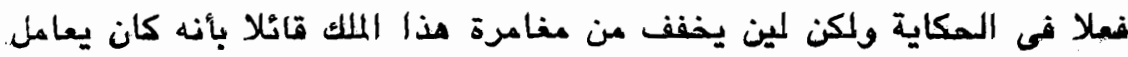

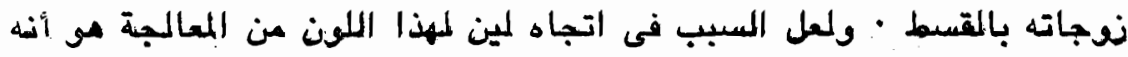

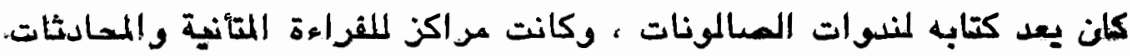

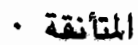

وكان يكفى أن بجد لين أى الشارة جسدية فم القضية متى ينسى تماما.

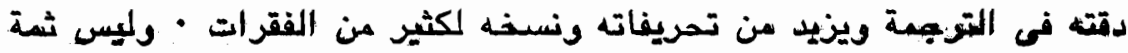

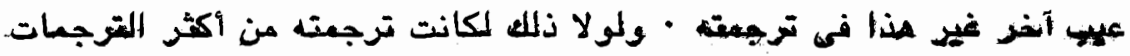

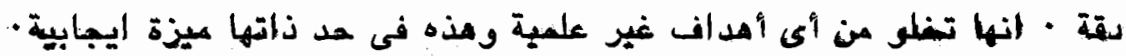

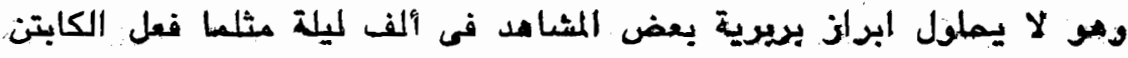

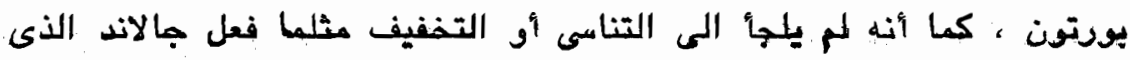

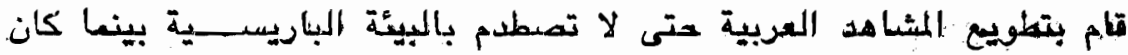

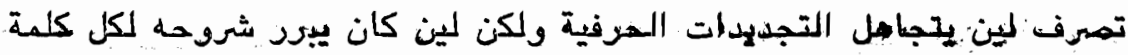

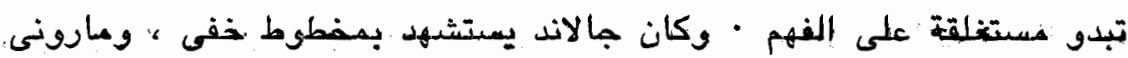

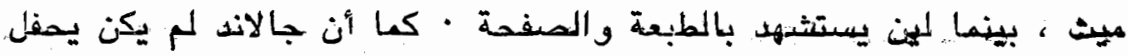

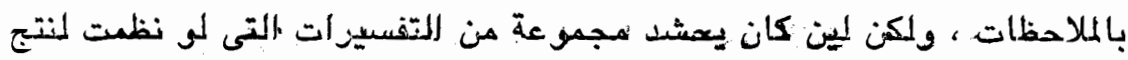

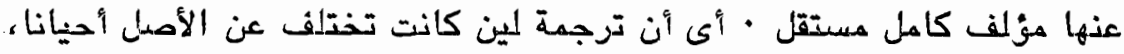

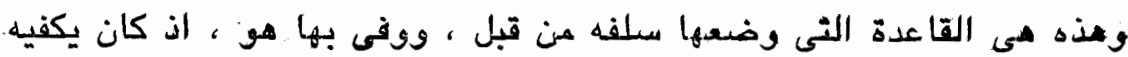

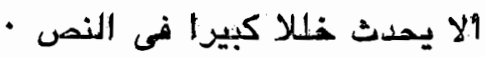

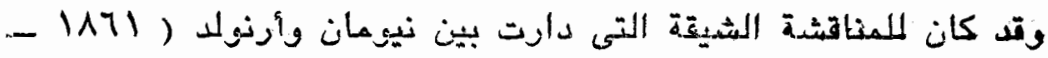

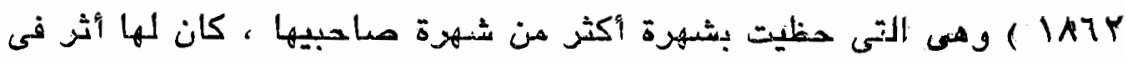

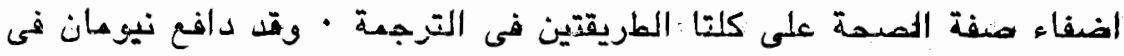

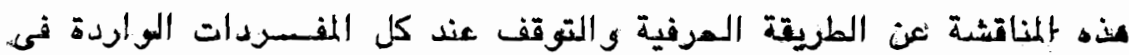




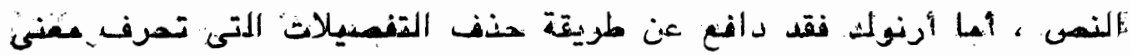

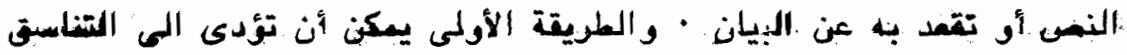

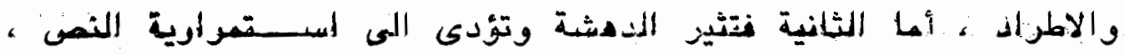

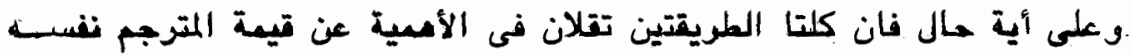

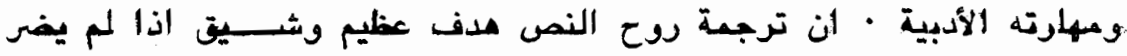

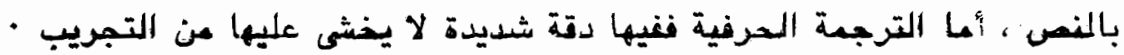

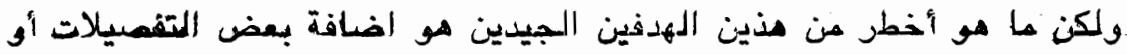

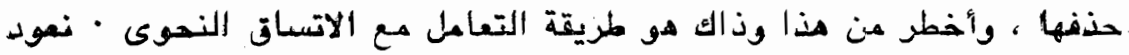

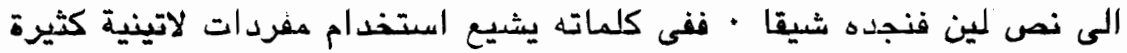

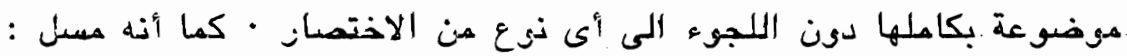

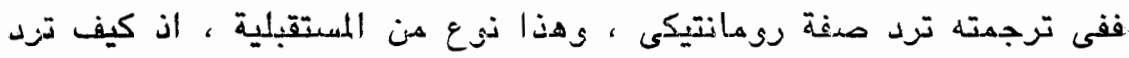

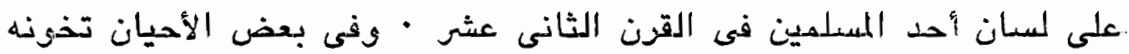

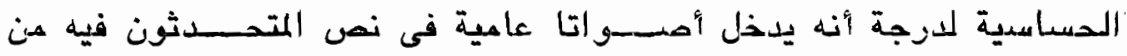

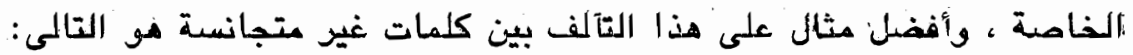
And in th is palace is the last information respecting lords collected in the dust.

وثمة مثال آخر يقىل : " باسم الجى الذى لا يمثت ولا يدق عليه الموت ، باسم

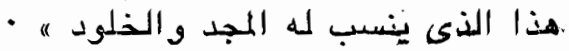

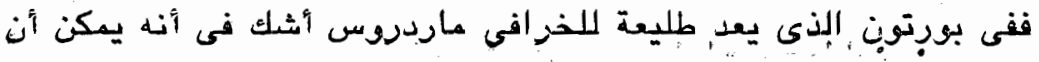

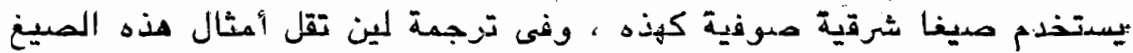

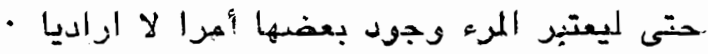

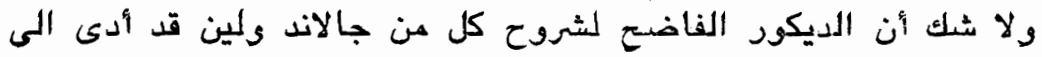

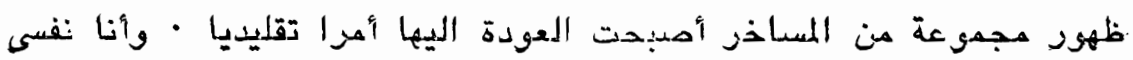
ثلقيت بدلوى فى هذا المعترك • ومعروف جدا أنهما لم يستكملا مشرهد المسكين

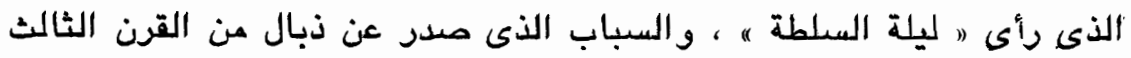

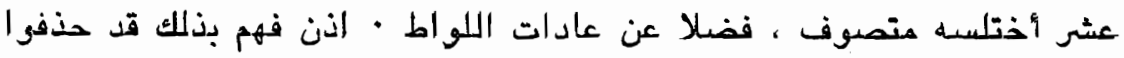

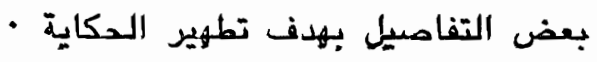

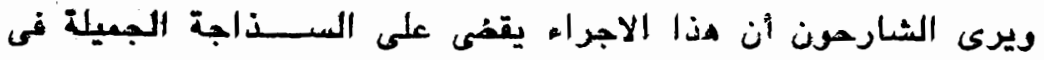

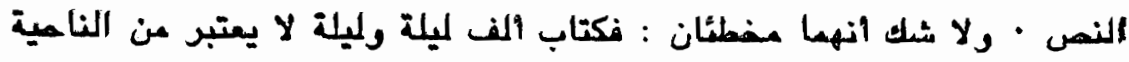




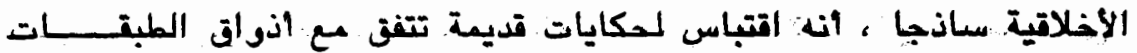

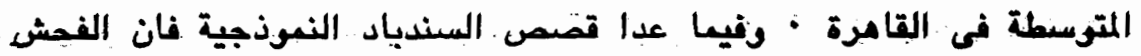

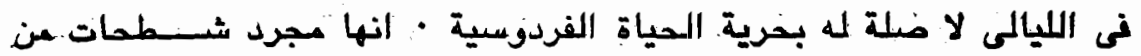

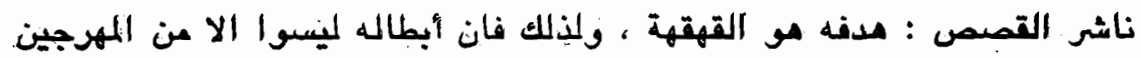

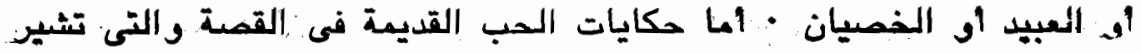

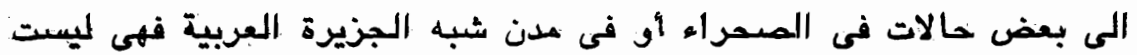

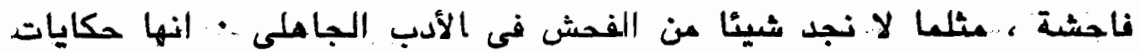

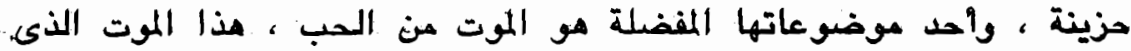

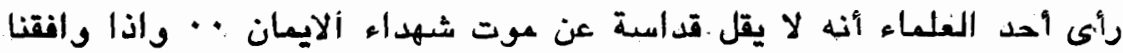

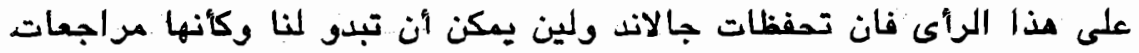

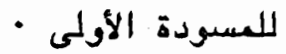

وثمة تعليل آخز أفضل من مذا يقول بأن الاشارة الى المشامد الجنسية

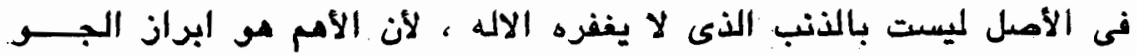

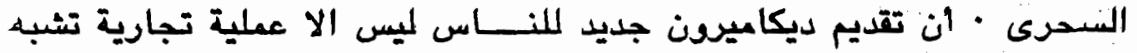

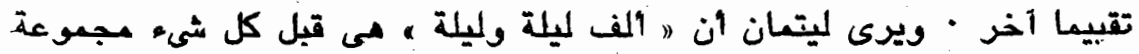

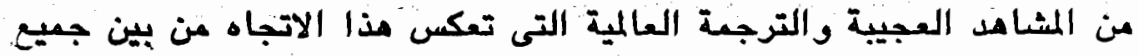

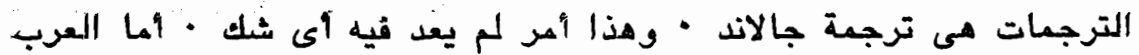

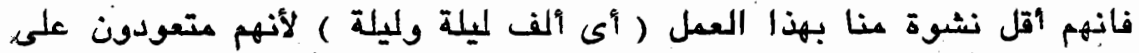

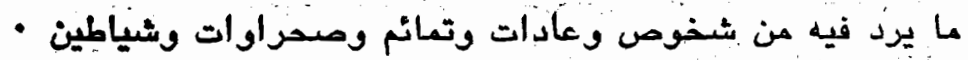

يقسم روفائيل كانسينوس أسنس فى احد كتبه بأنه يستطيع أن يحيى.

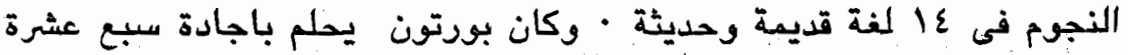

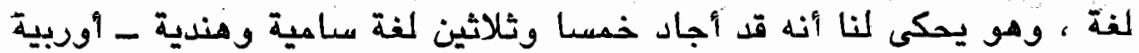

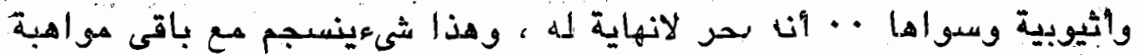

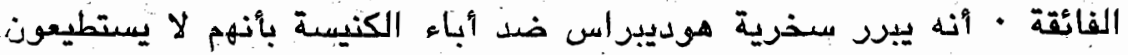

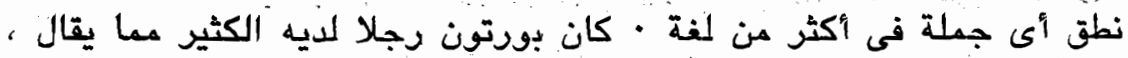

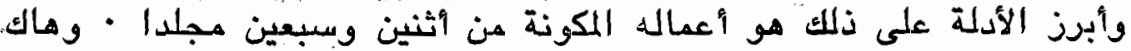

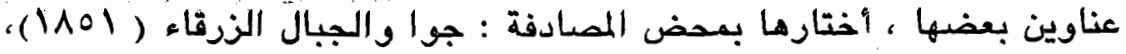

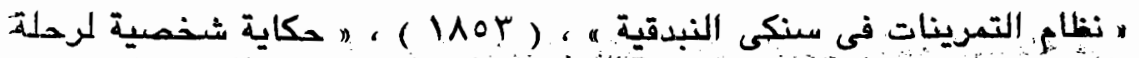




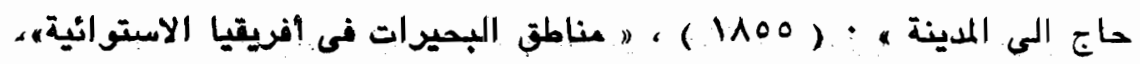

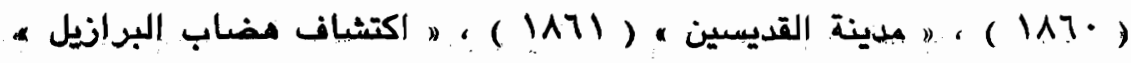

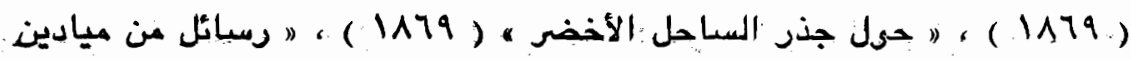

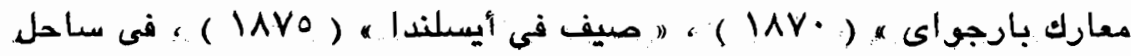

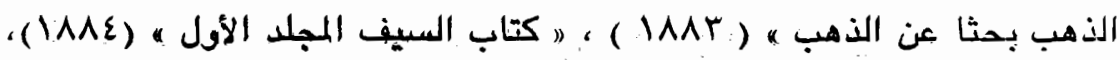

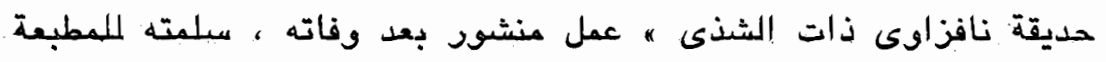

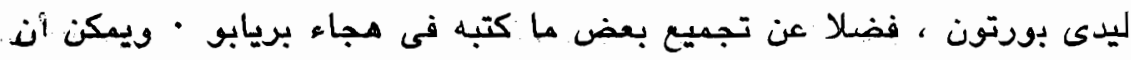

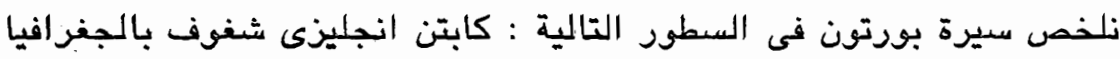

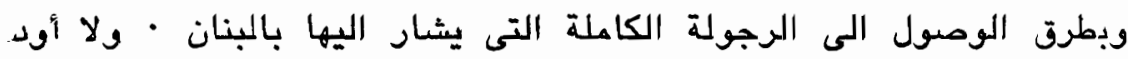

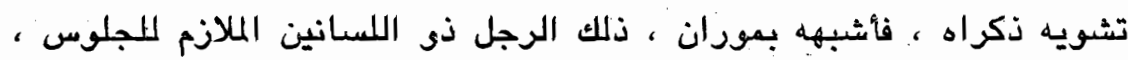

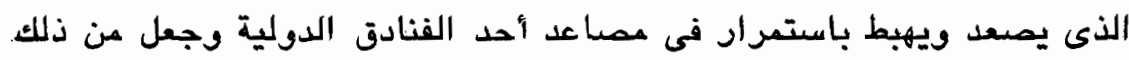

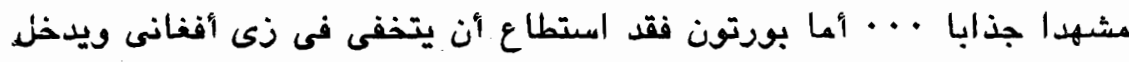

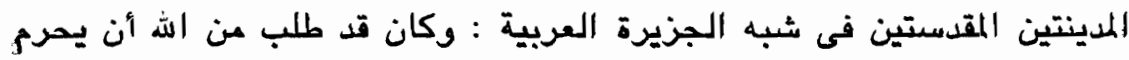

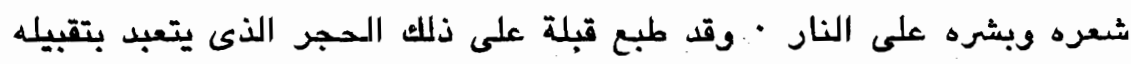

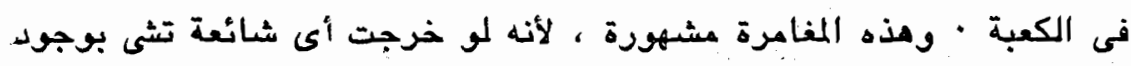

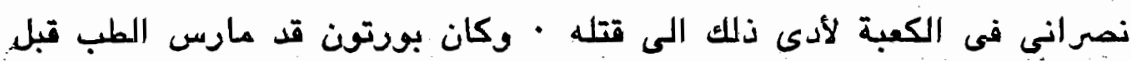

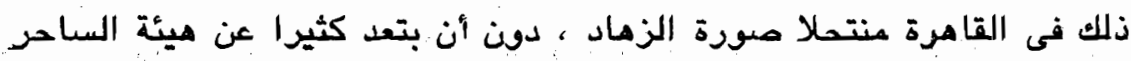

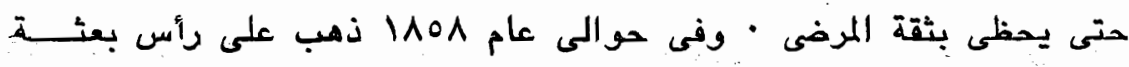

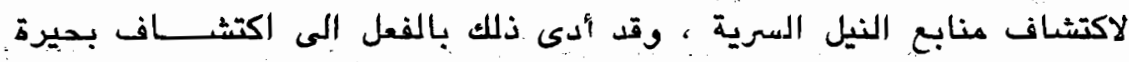

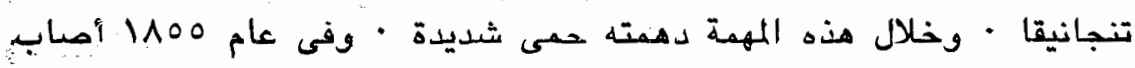

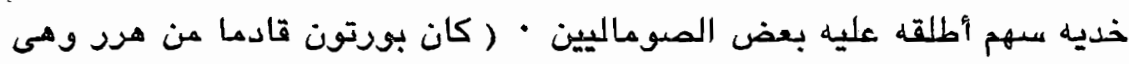

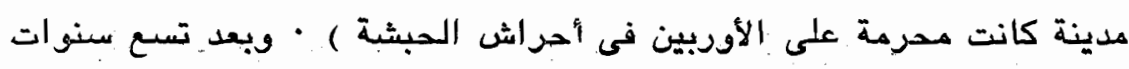

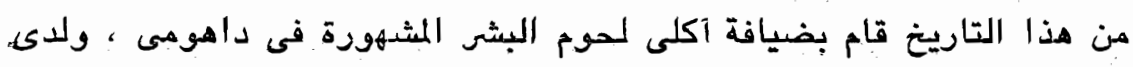

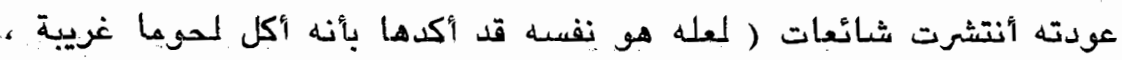

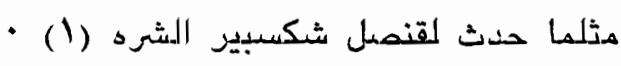

...On the Alps It is reported, thou didst eat strange flesh Which some did die to look on...

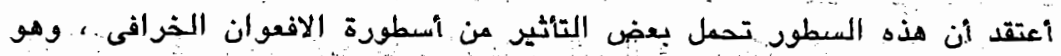

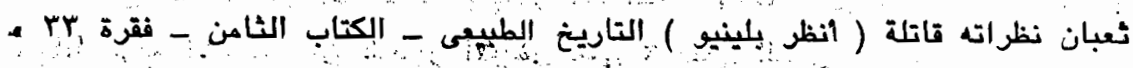




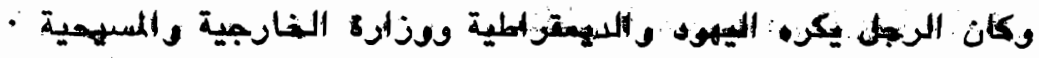

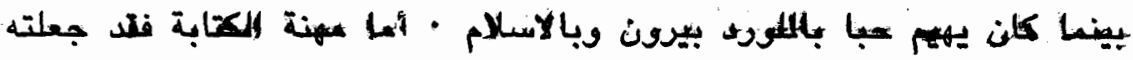

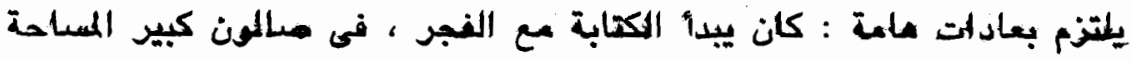

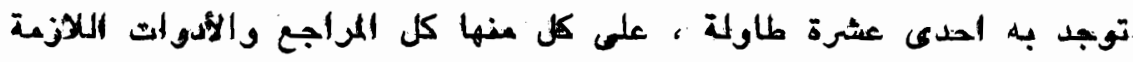

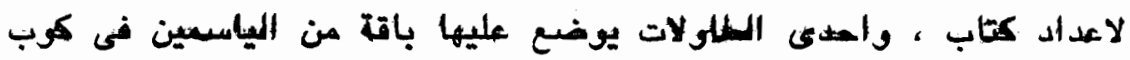

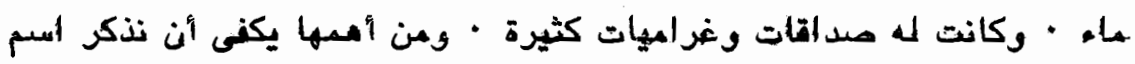

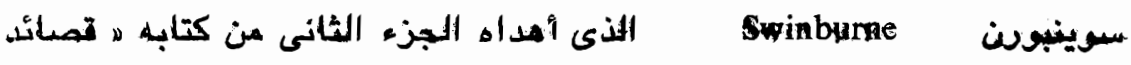
.

in recognition of a friendship which : I must always count among the highest honours of my life.

$$
\text { وقد رثاه فمى كثير من قصائده : }
$$

وكان بورتون رجل السيف والقلم · ولعله أستطاع 19ن يتمثــل قول

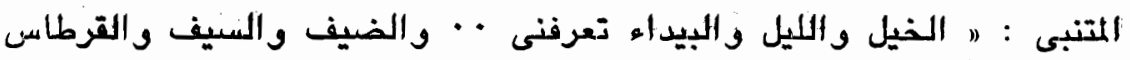

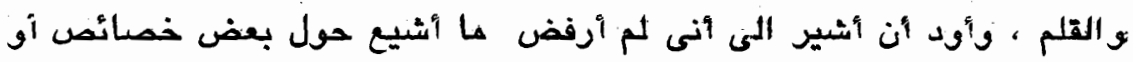

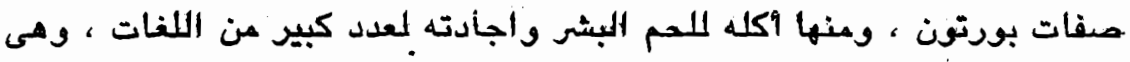

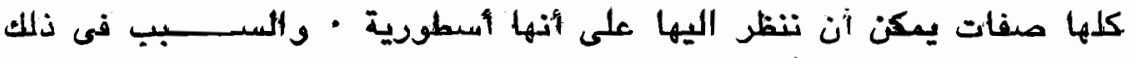

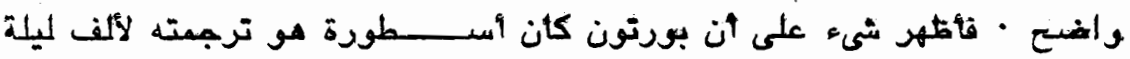
-

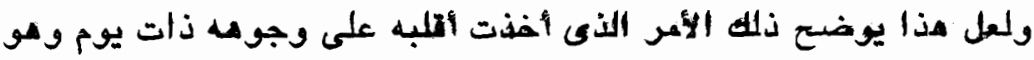

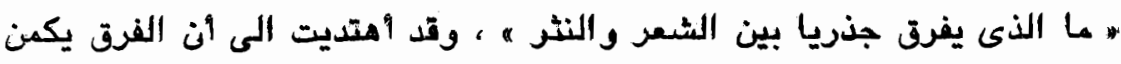

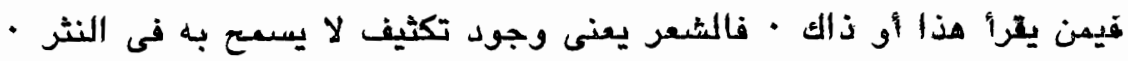

ولم يذكر الكاتب شيئا عن قدرات هذه الحية ، ولكن لابد أن القتران فكرتى النظرة

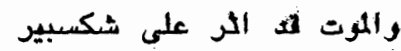

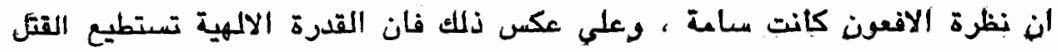

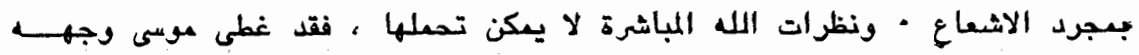

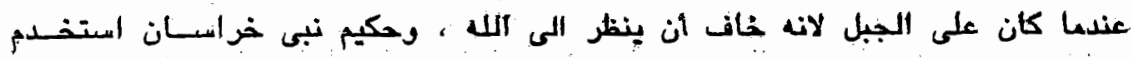

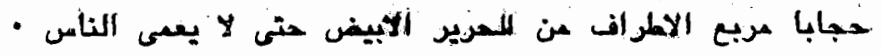


وشىء هن هذا القبيل بحدث فهم همل بورتون : ان له مكانة لا تساويها مكانة

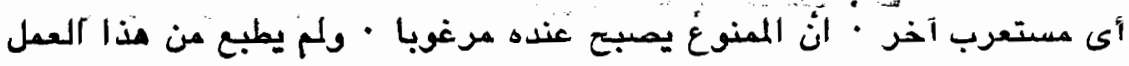

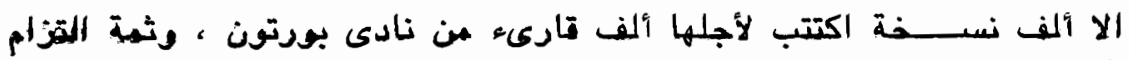

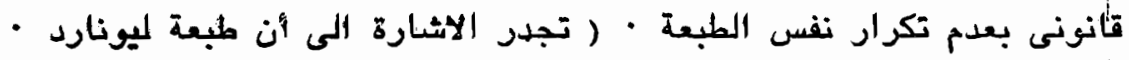

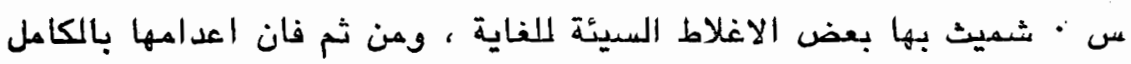

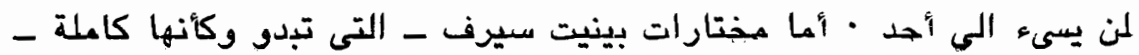

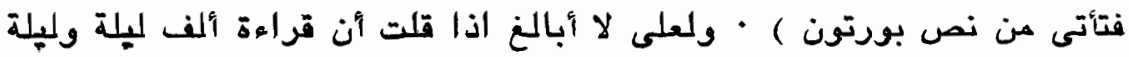

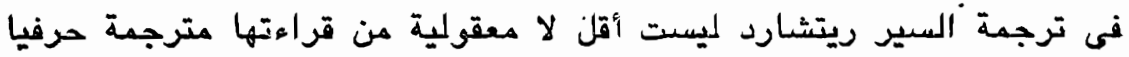

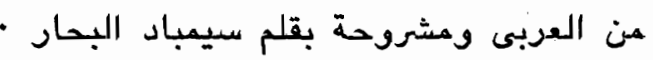

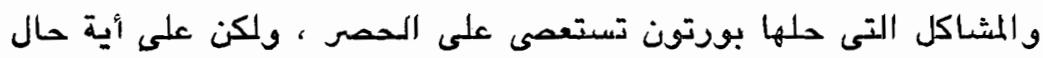

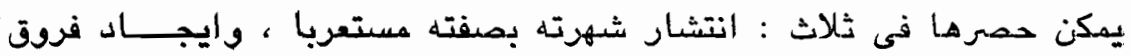

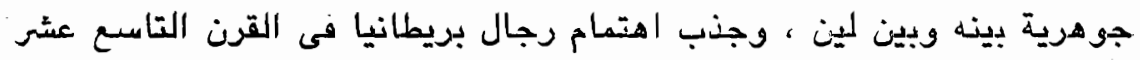

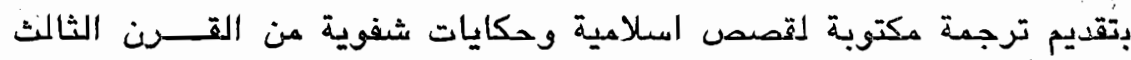

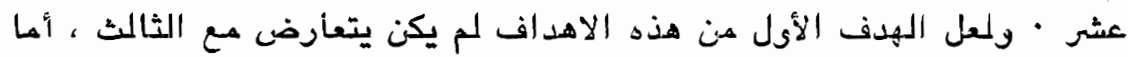

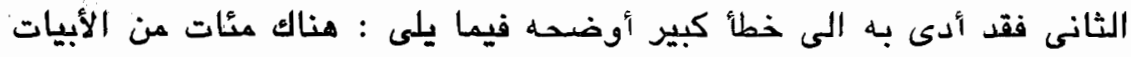

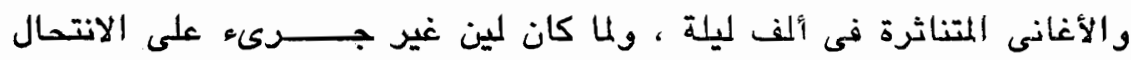

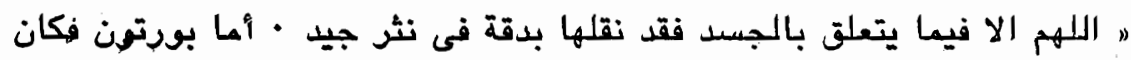

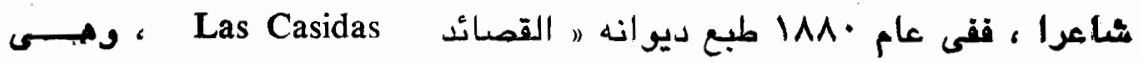

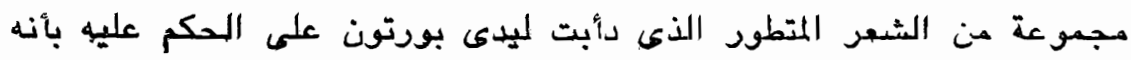

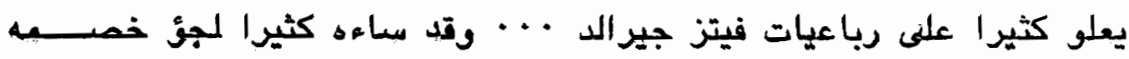

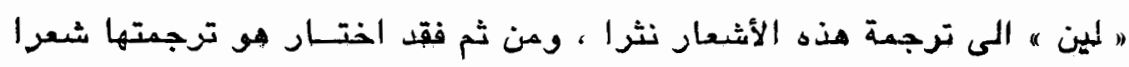

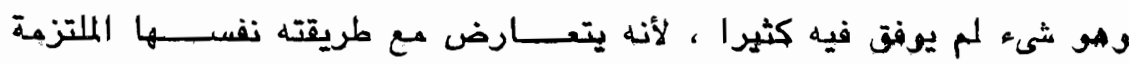

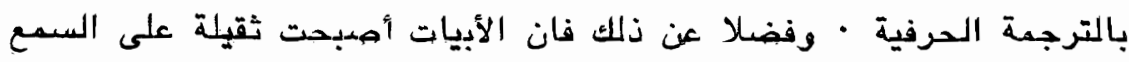

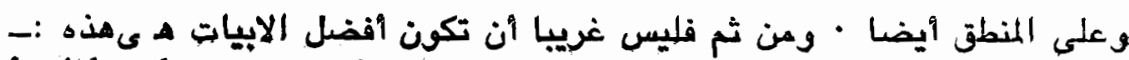
A night whose stars refused to run their course, A might of these which never seem outworn: Like Resurrection-day, of longsome length to

him that Watched and Waited for the morn.

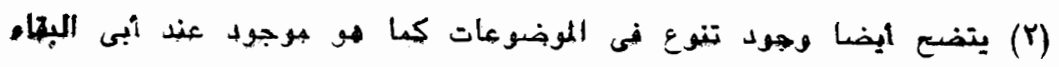

Whiere is the wight who peopled in the past Hind-land the the Tyrant played?... 


\section{رلعل أسوأ الأبيات ليست مى الابيات التالية ممسب ؛ -}

A sun on Wand in Knoll of sand she showed, Clad in her cramoisyhued chemisette: Of her lips' honey-dew she gave me drink. And with her rosy cheeks quencht fire she set.

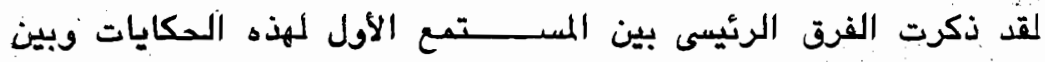

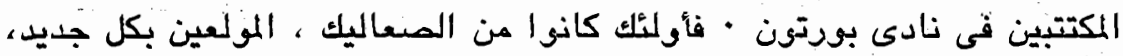

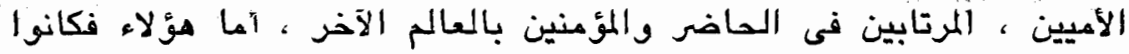

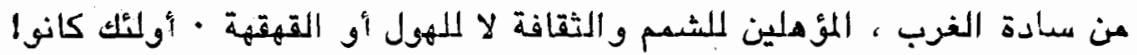

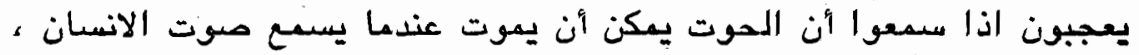

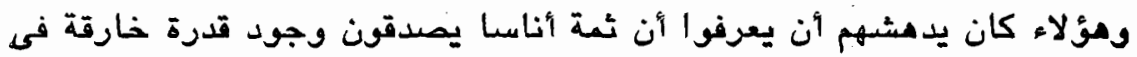

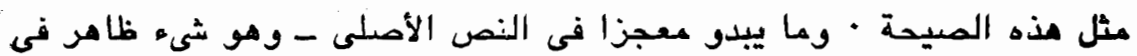

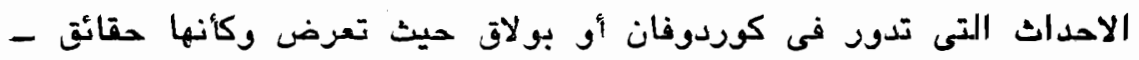

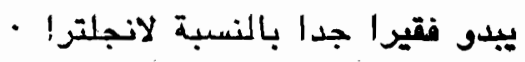

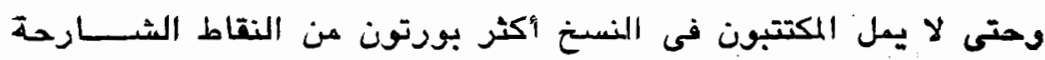

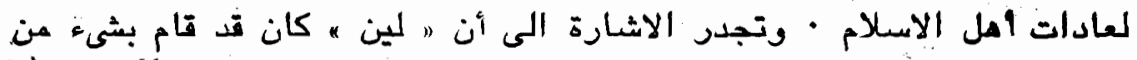

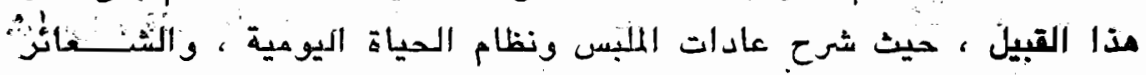

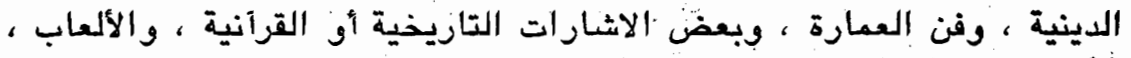

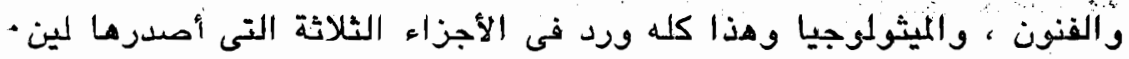

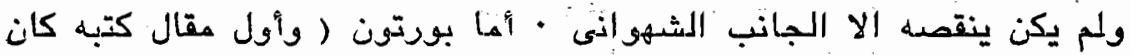

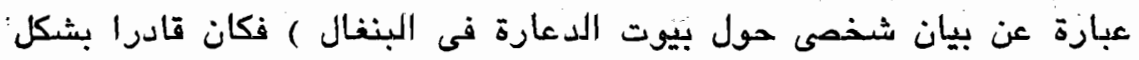

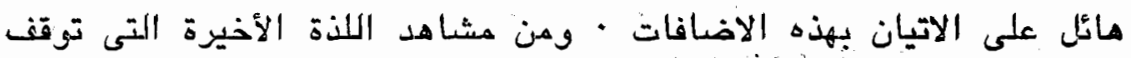

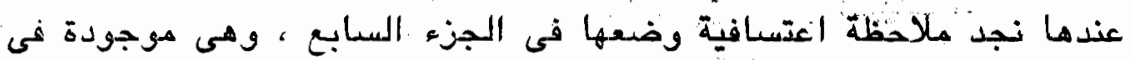

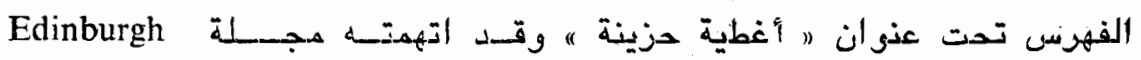

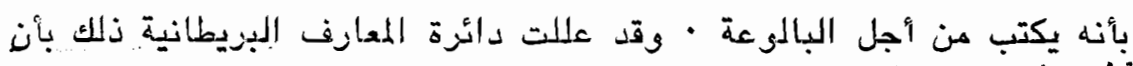

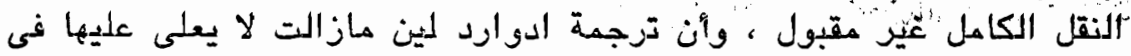

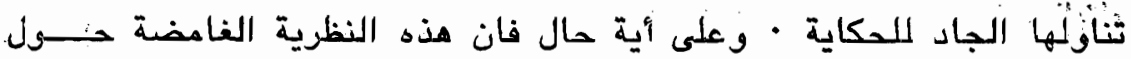

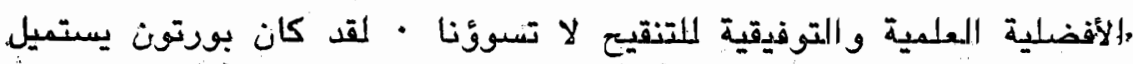

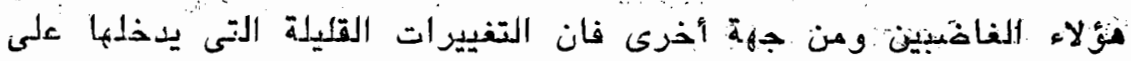

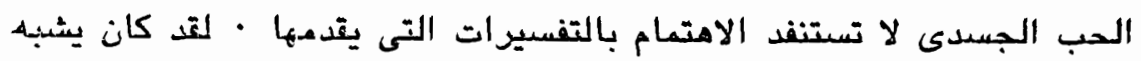




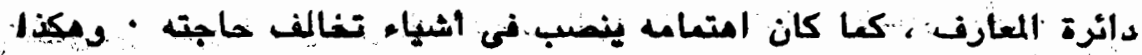

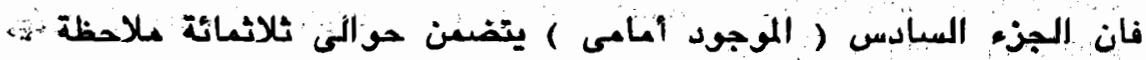

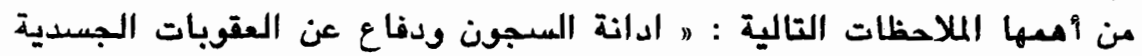

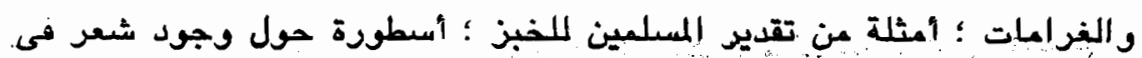

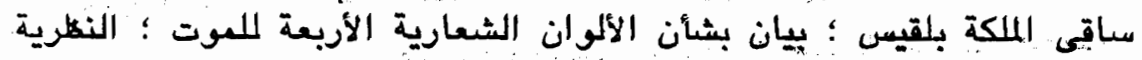

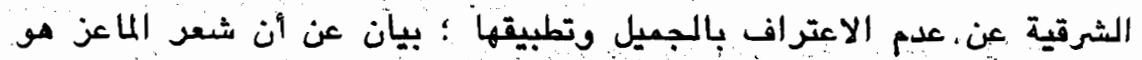

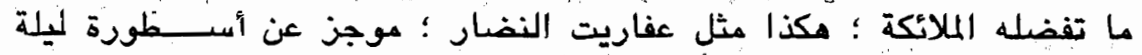

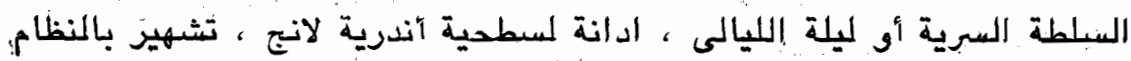

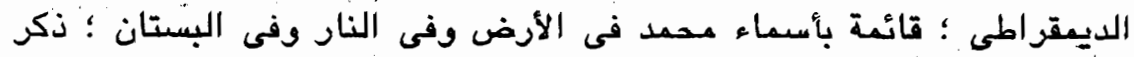

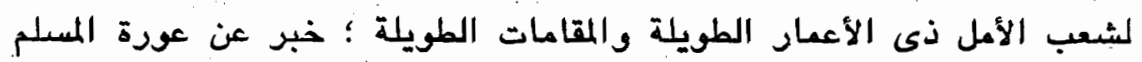

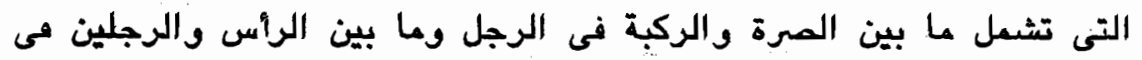

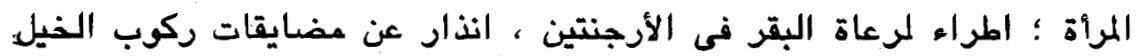

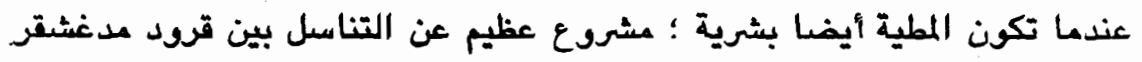

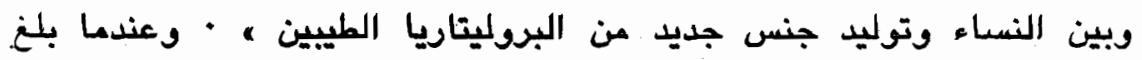

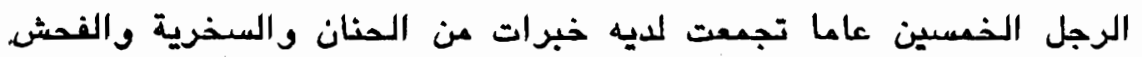

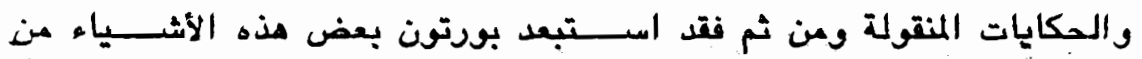
ملاحظاته والهات

وتظل المشكلة الرئيسية قبائمة ومى كيف أمكن تسلية فرسان القــــن

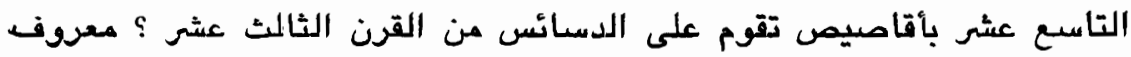

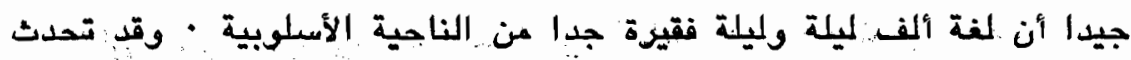

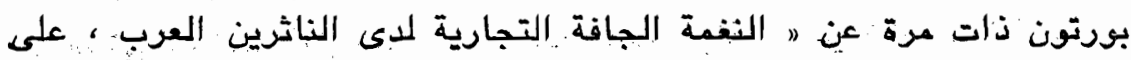
عكس ما هو معرون عن الفرس مبن مبالغات فى استخدام المجاز ، أما ليتمان

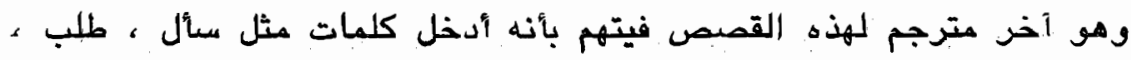

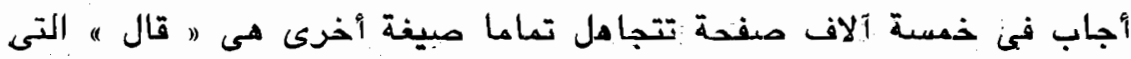

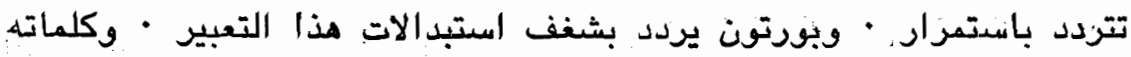

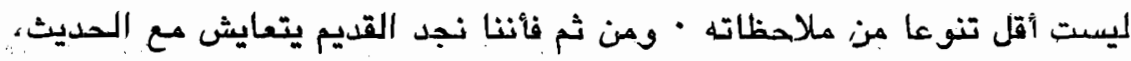

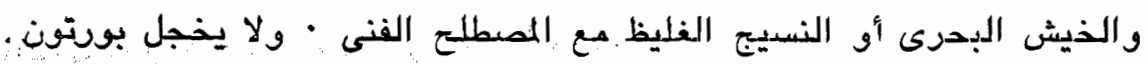

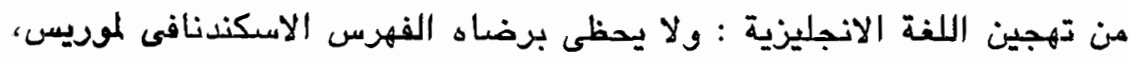

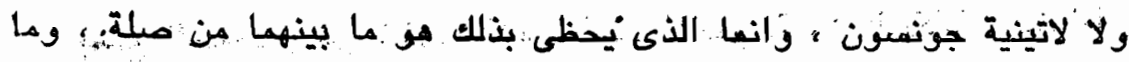




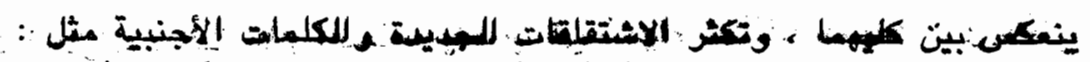
Castrato, inconséquence, hauteur, in gloria, bagnio, langue foutré, pundonor, vendetta, wazir.

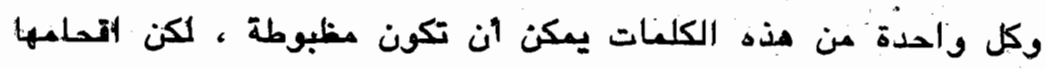

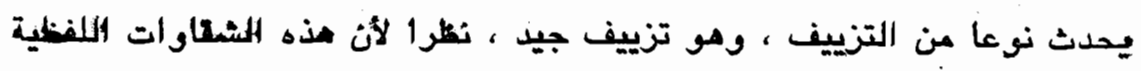

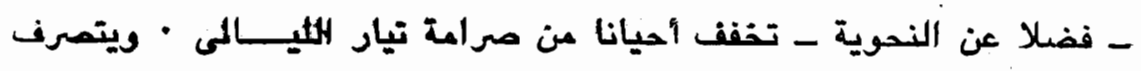

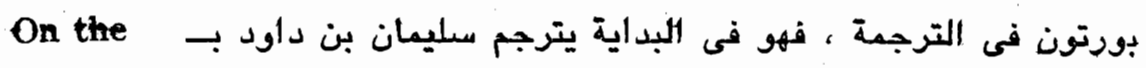

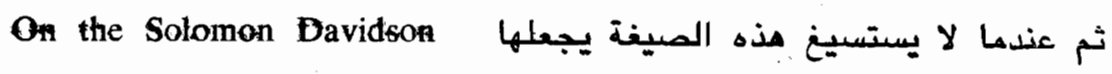
انه يجعل من الملك الذى يشير اليه ألمترجمون الآخرونعلى (Twain he peace

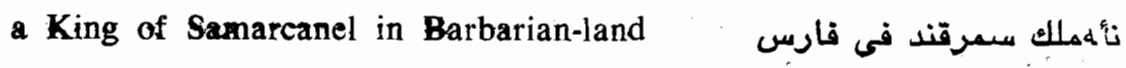

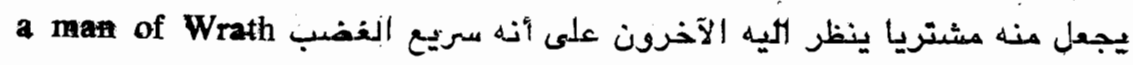

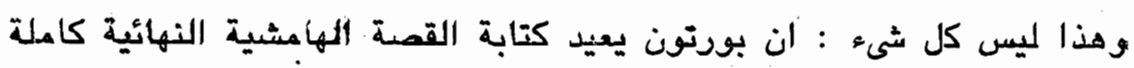

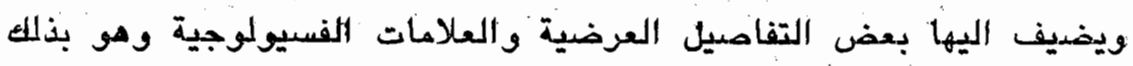

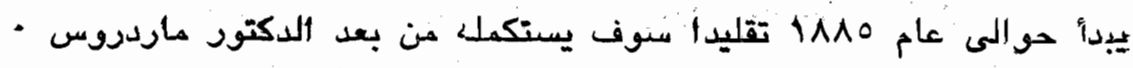

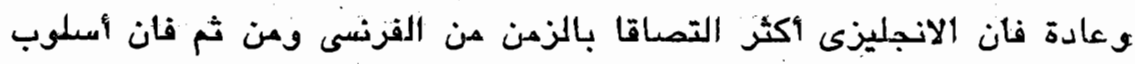

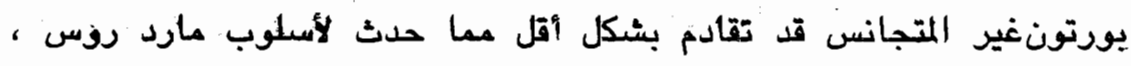

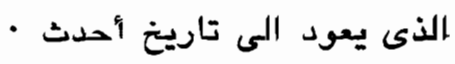

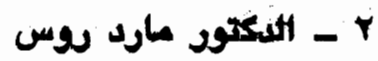

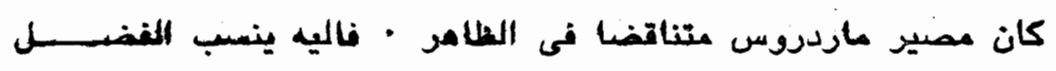

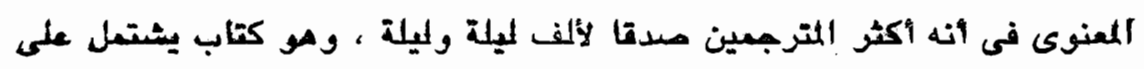

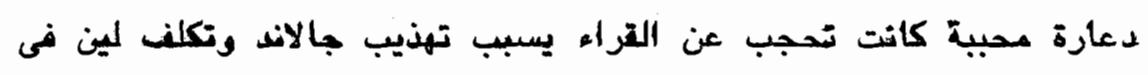

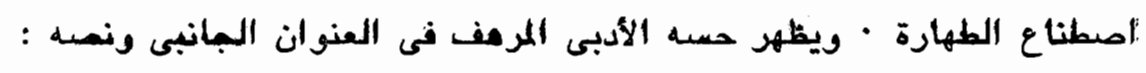

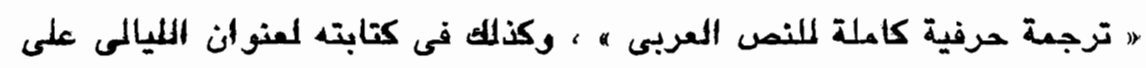

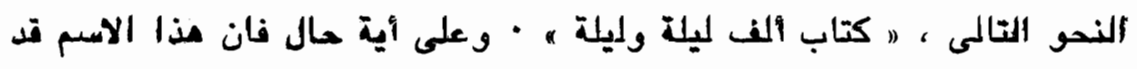

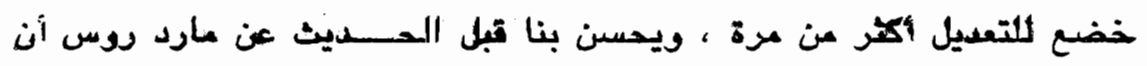

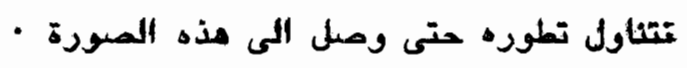

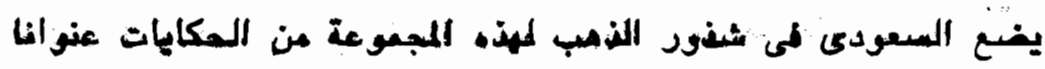

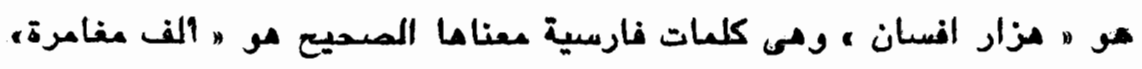




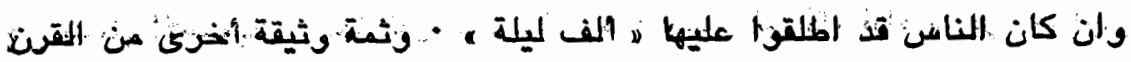

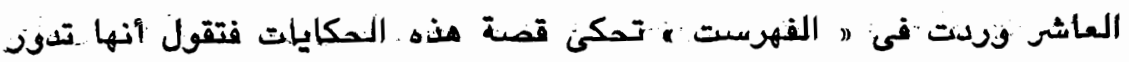

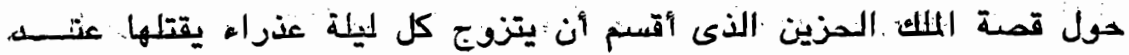
القجر ، حتى كانت شهززاد التى أخذت تستميله بدكايات عجية الفية حتى بلغت

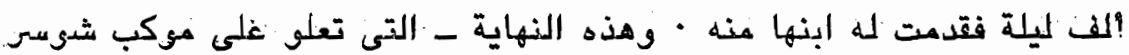

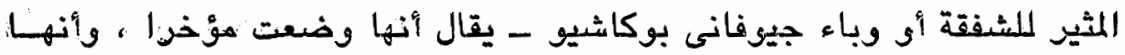

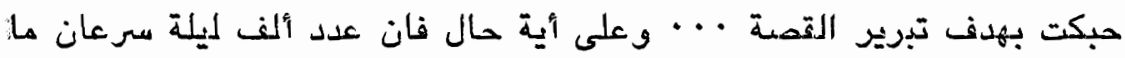

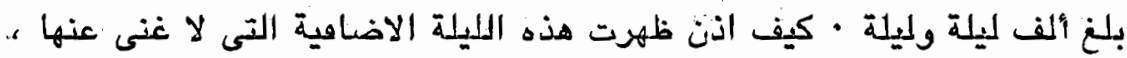

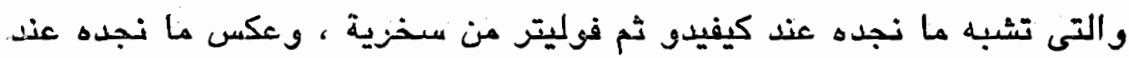

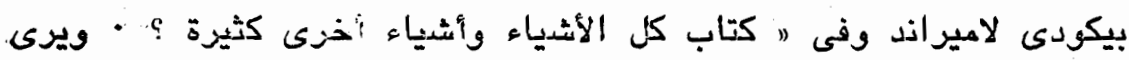

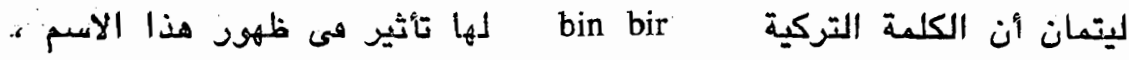

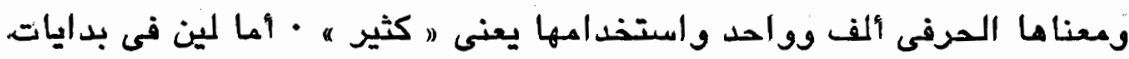

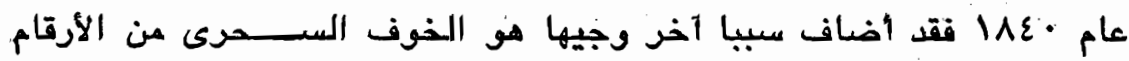

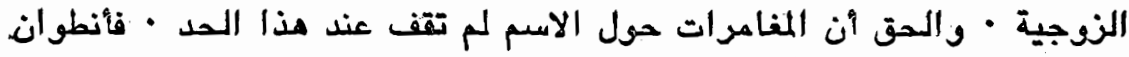

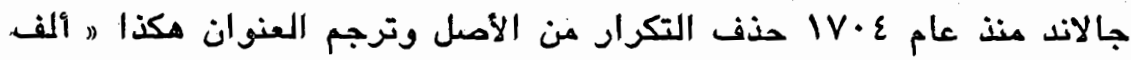

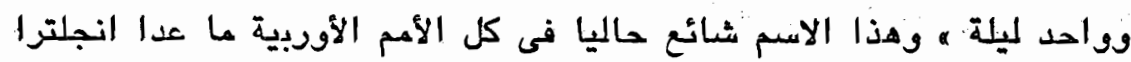

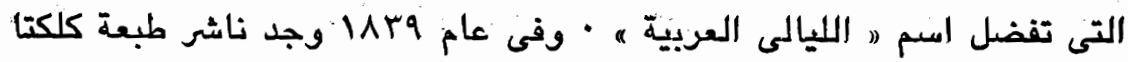

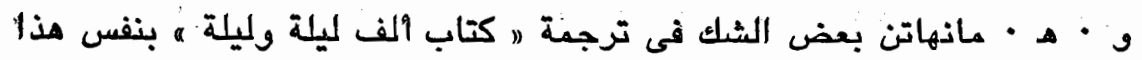

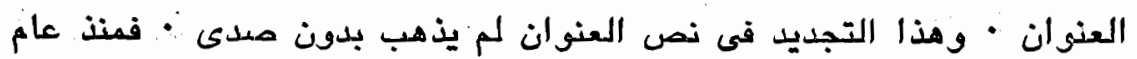

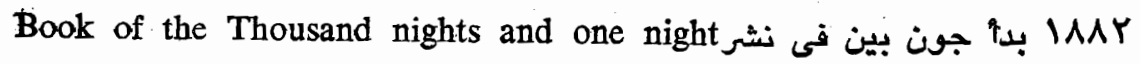

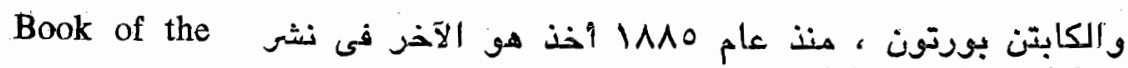

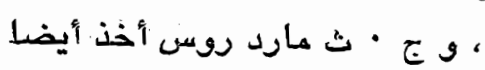

Thousand nights and a night

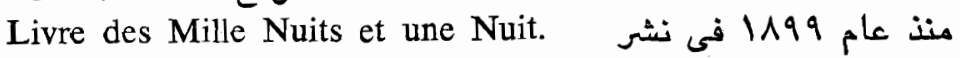

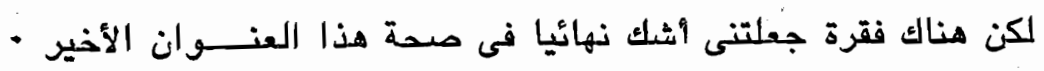

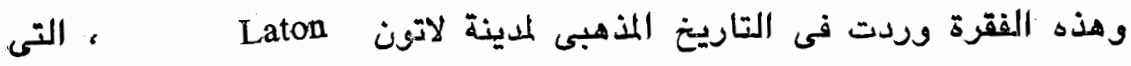

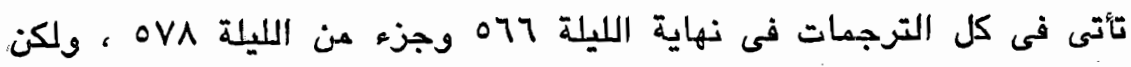

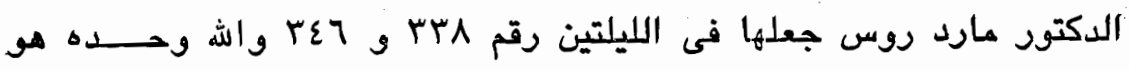

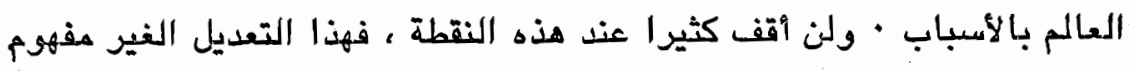

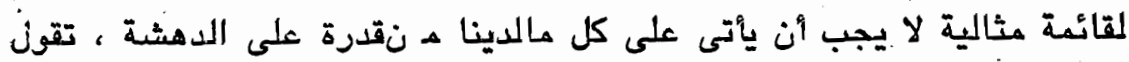

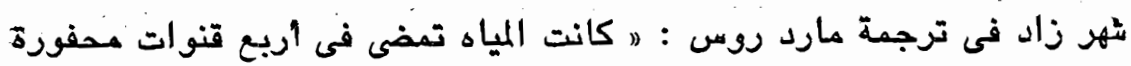




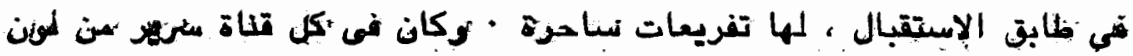

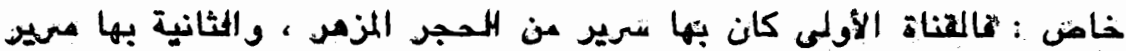

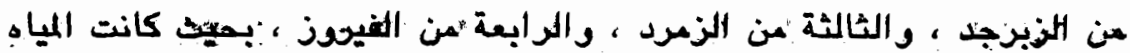

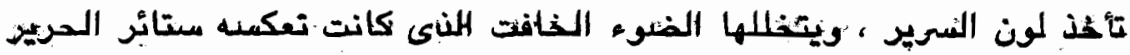

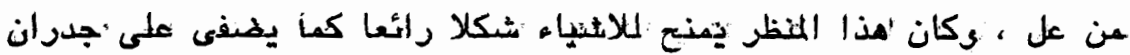

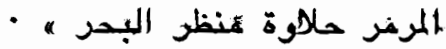

وهذه اللفقرة أقبلها على أنها وصف من النثر المرثى على طريقة تصوير

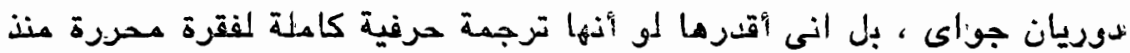
القرن الثالث عشر · ولكنها فى الوقت نفسه تروعنى بشكل هائل ، وأسباب

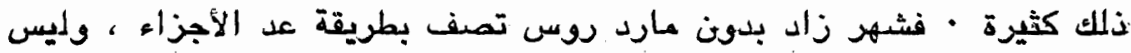

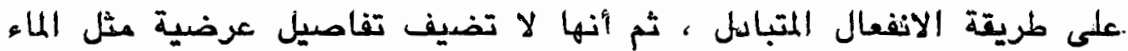

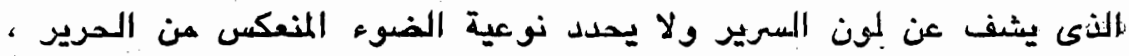

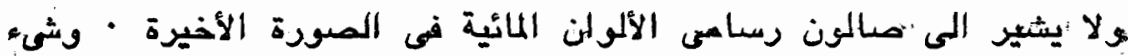

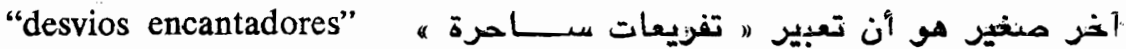

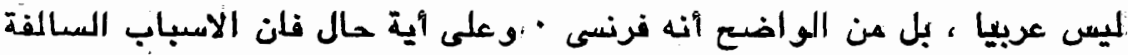

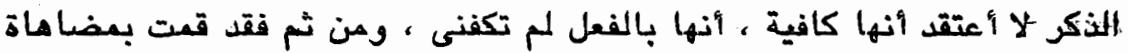

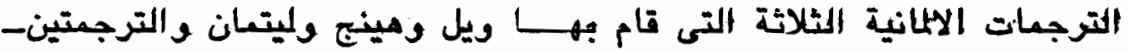

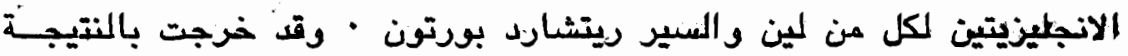

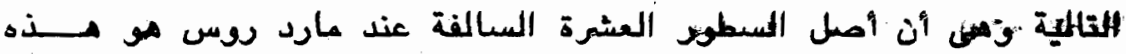

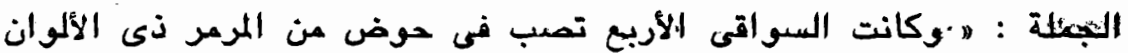
- المتعددة

ان حواثىى مارد لرس ليست متناسقة · ففى بعض الأحيان تأتى مختلة

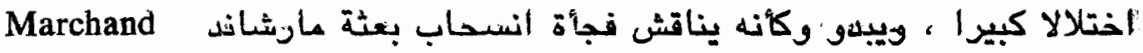

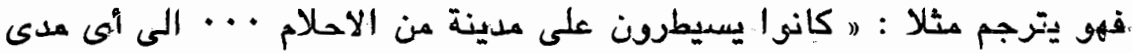

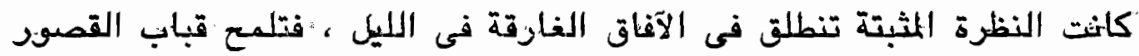

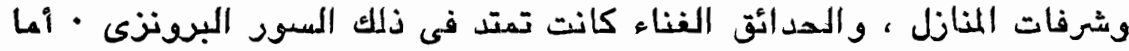

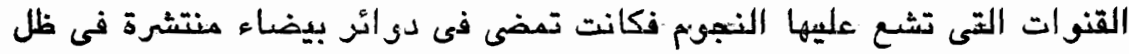

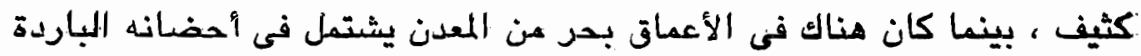

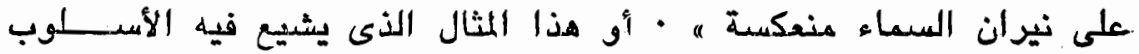




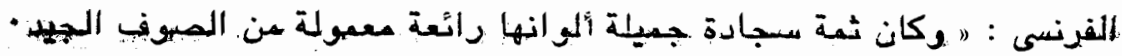

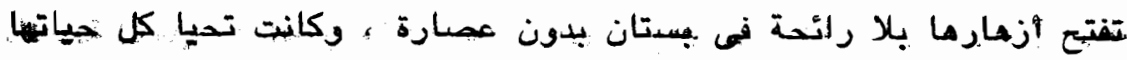

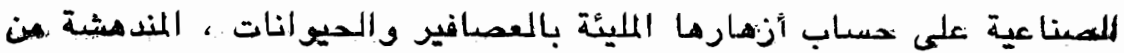

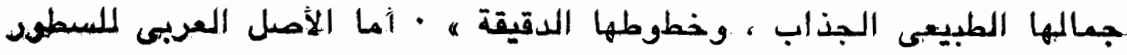

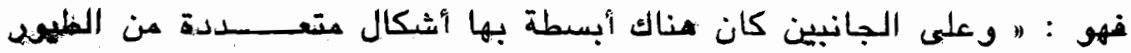

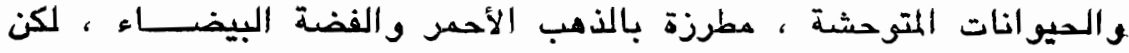

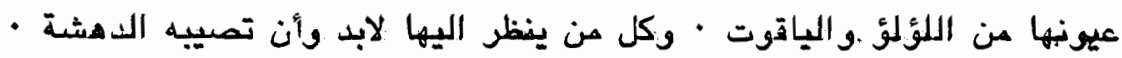

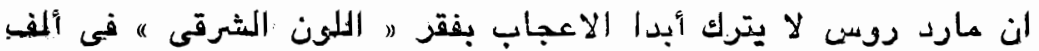

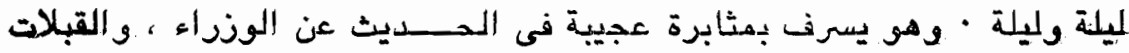

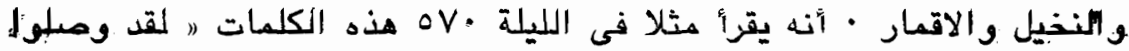

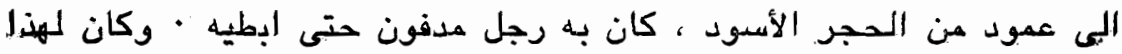

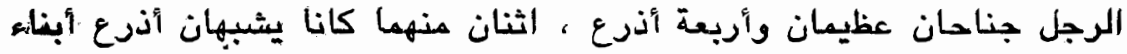

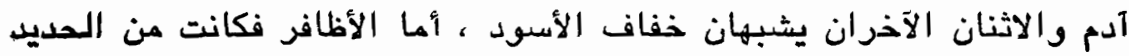

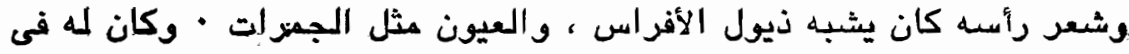

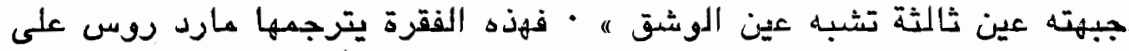

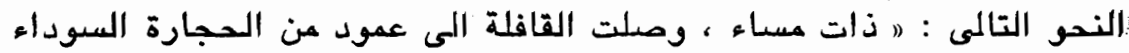

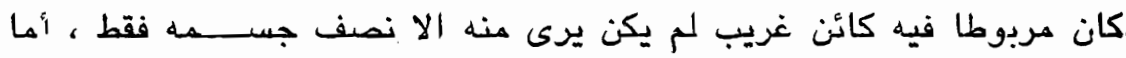

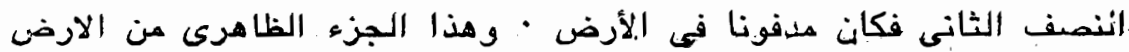

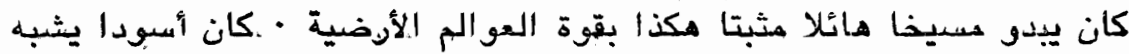

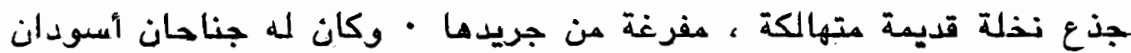

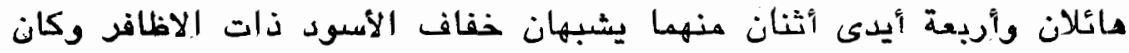

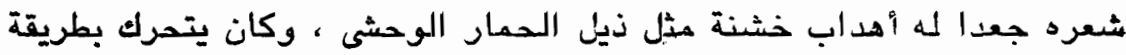
وحشية فوق جمجمته الرهيبة · وتحت قوسيه المداربين كانت تلمع حدقتان

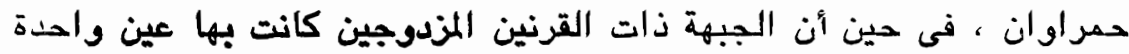

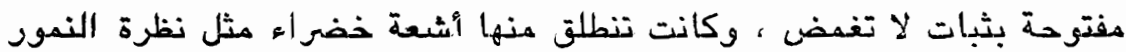

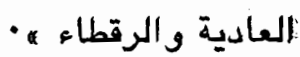

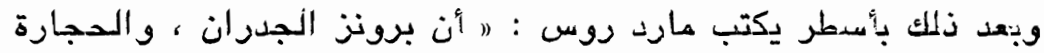

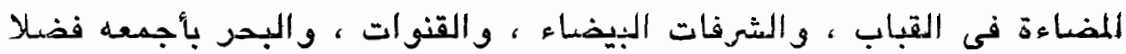

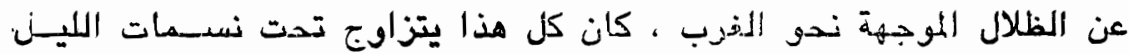




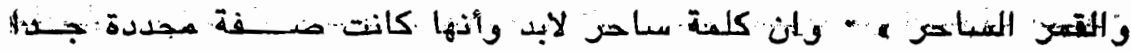

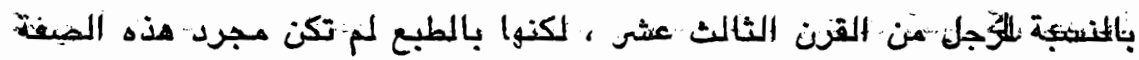

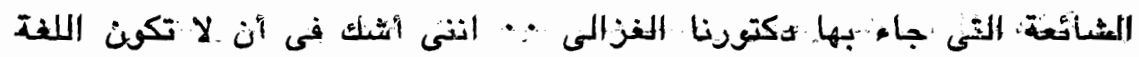

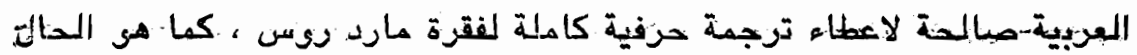

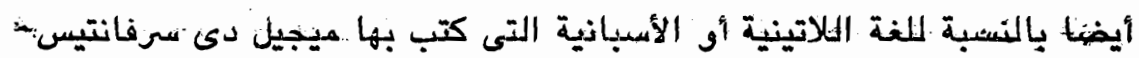

ويتوسنح كتاب ألف ليلة وليلة فى طريقتين ، أولاهما شكلية محضة وهنح.

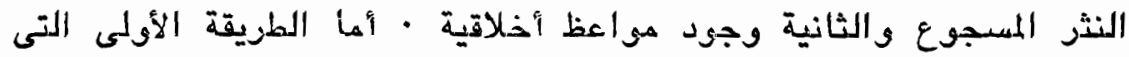

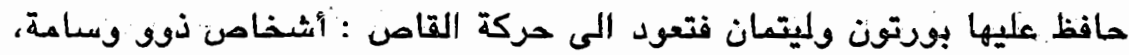

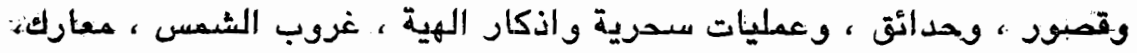

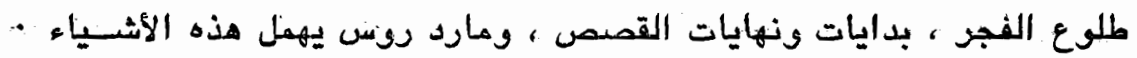

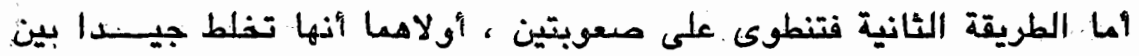

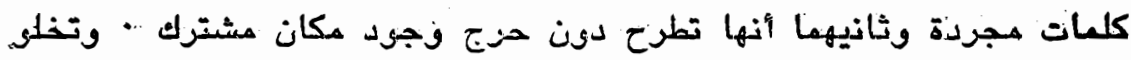

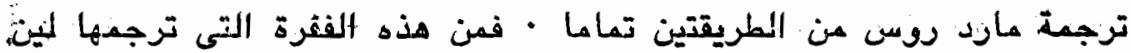

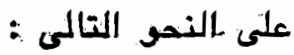

And in this palace is the last information respecting lords collected in the dust,

نجد الدكتور مارد روس لا يأخذ منها الا الكلمات التالية : " مضى كل.

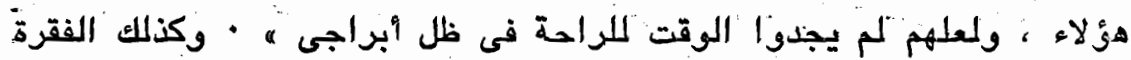

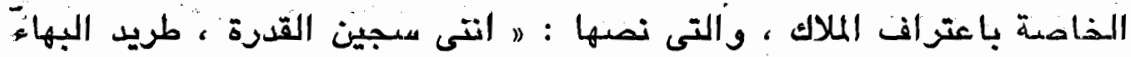

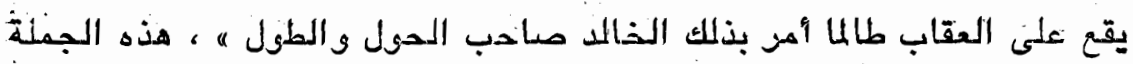
يترجهها مارد روس على النحو التالمى : ، أنا هنا مقيد بالقوة غئ فير ألمرئيسة.

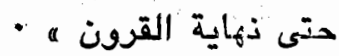

كما أن السحر ليس لمه فى ترجمة مارد لوس أثر كبيز • أنه لا يقدز

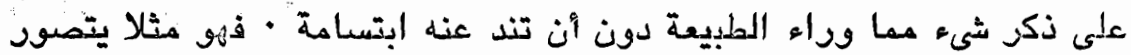

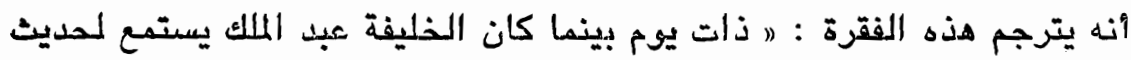

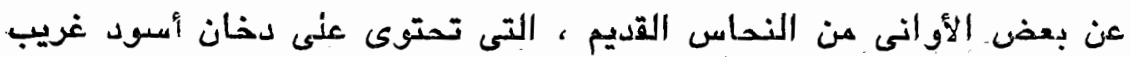

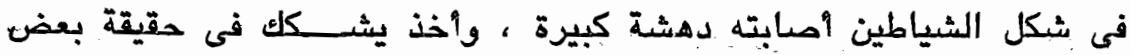




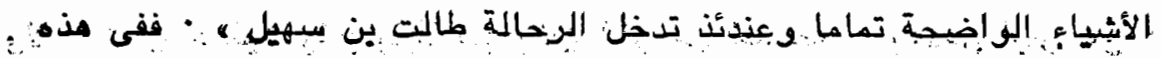

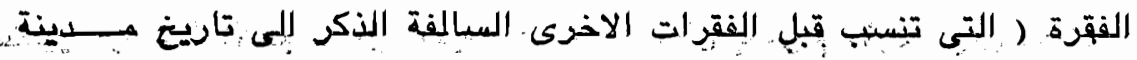

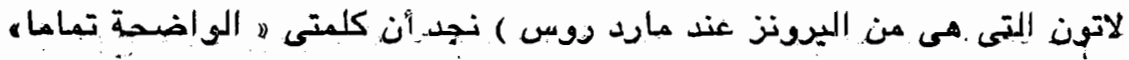

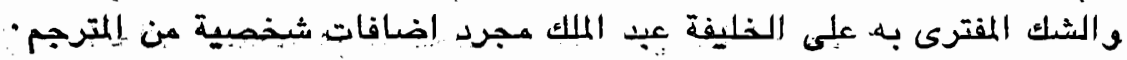

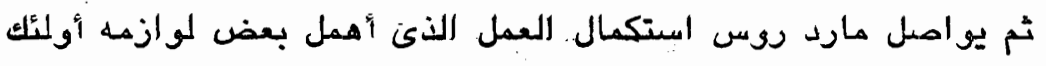

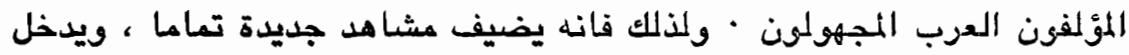

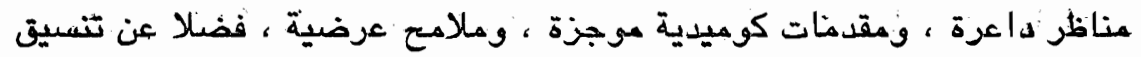

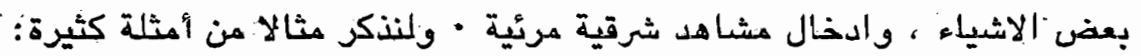

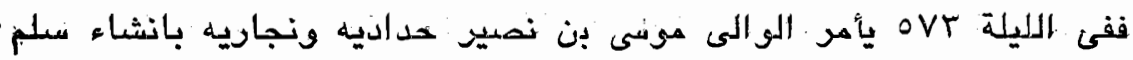

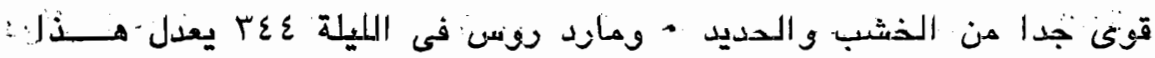

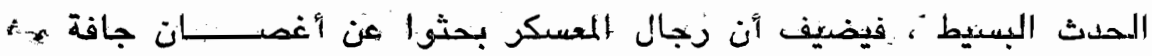

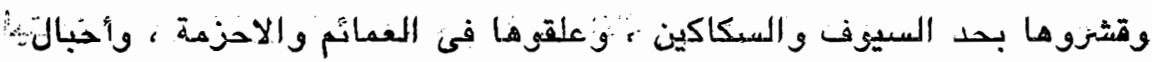

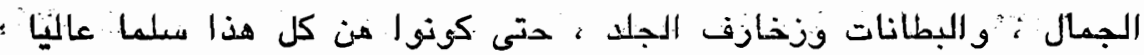

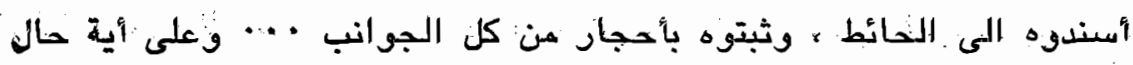

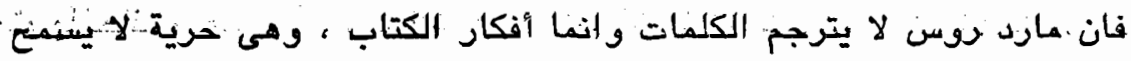

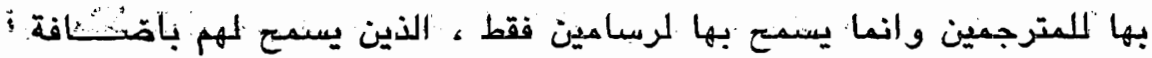

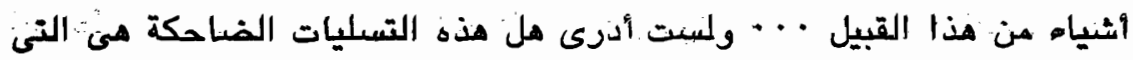

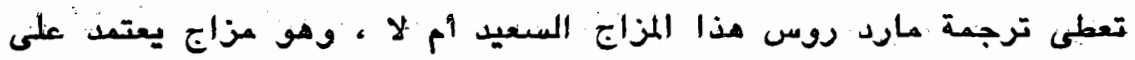

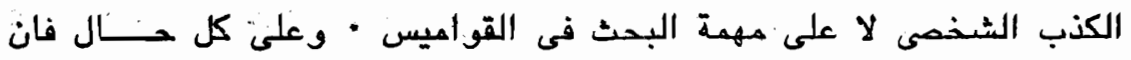

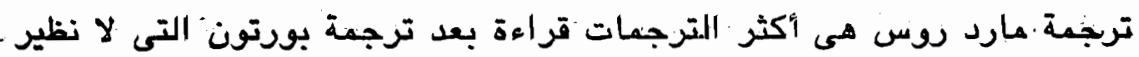

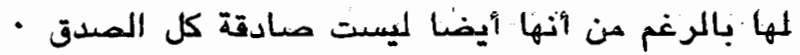

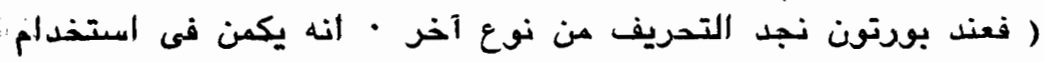

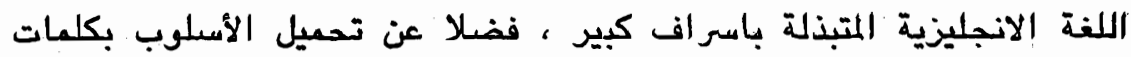

$$
\text { • قديمة وروعرة ) }
$$

وانى أرثى ( لنفسى لا لمارد روس ) لأن السطور العابقة تبدو وكانها

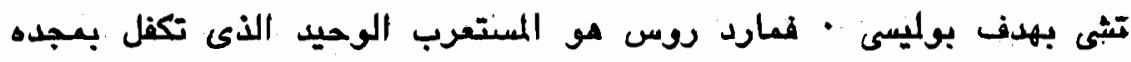

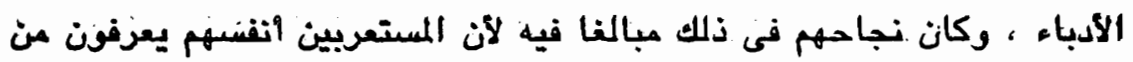

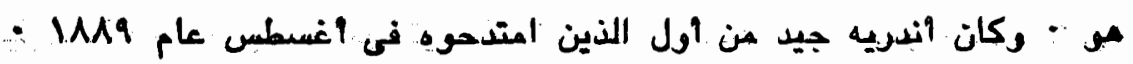




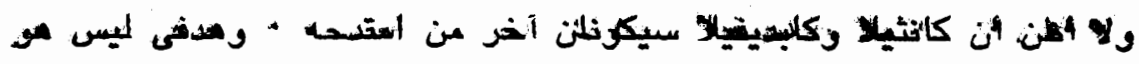

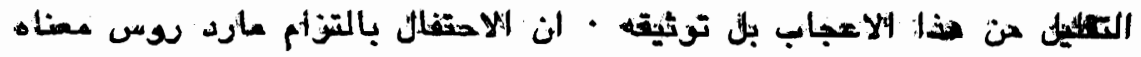

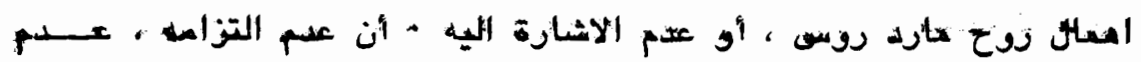

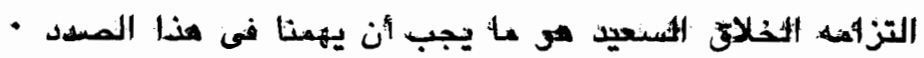

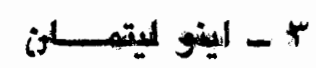

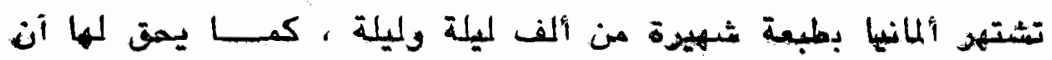

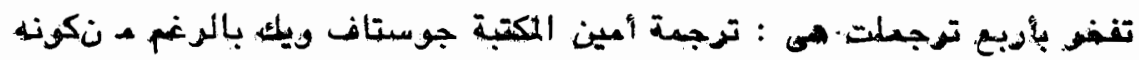

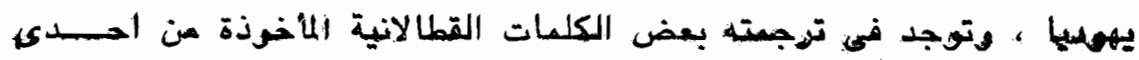

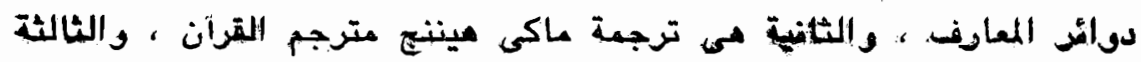

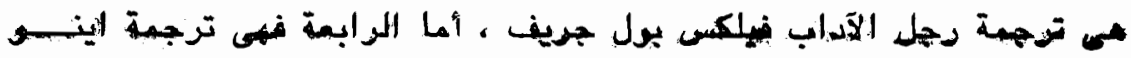

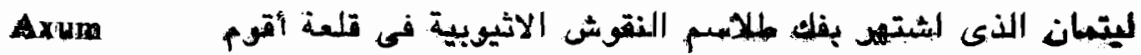

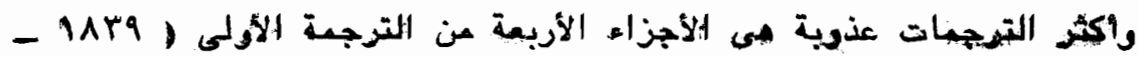

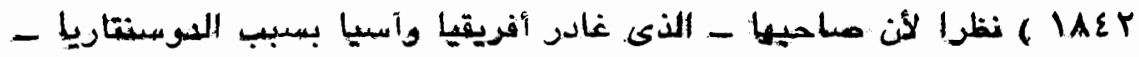

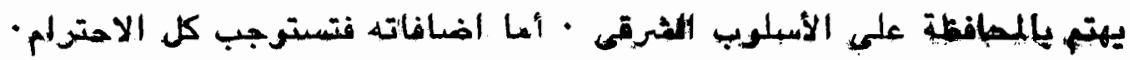

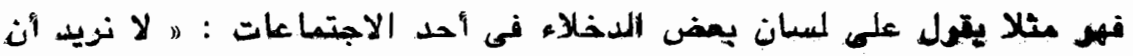

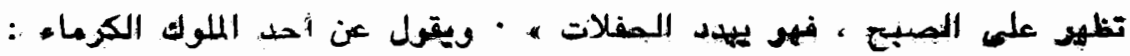

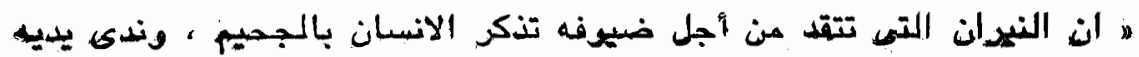

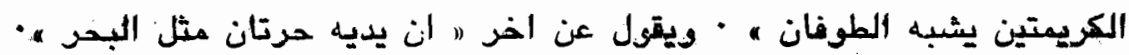

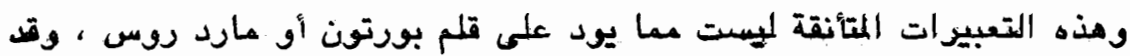

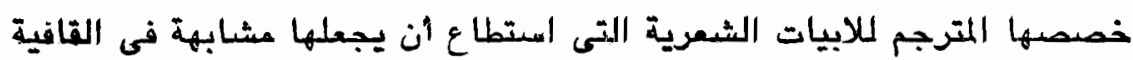

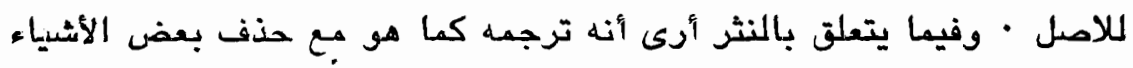

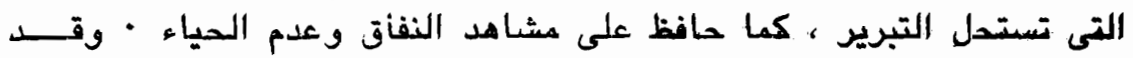

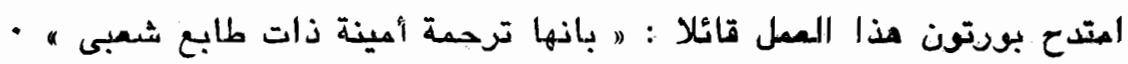

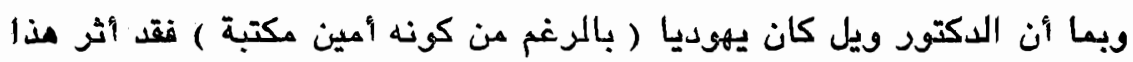

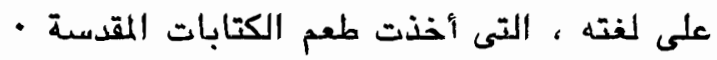

موأ.....

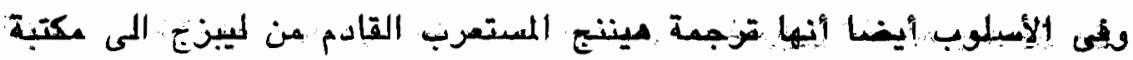

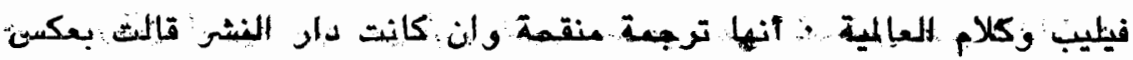




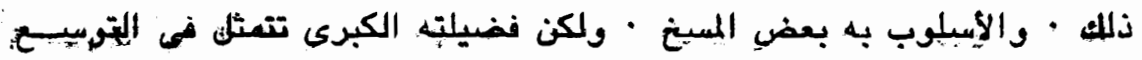

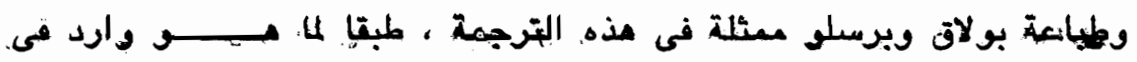

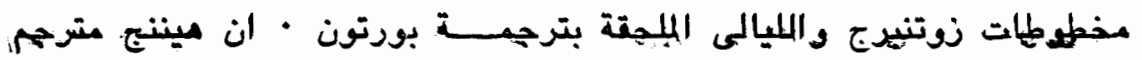

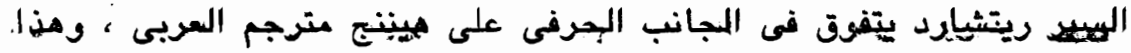

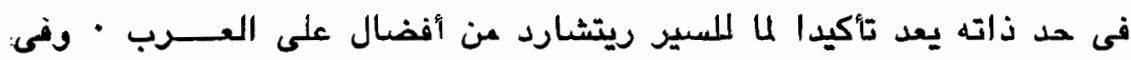

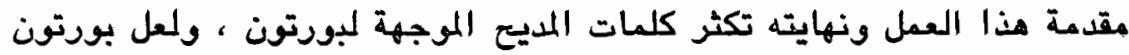

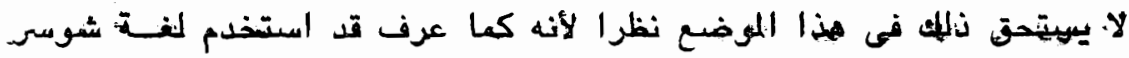
- Chauger

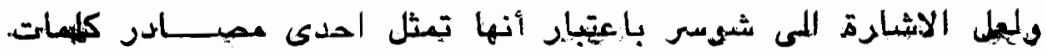

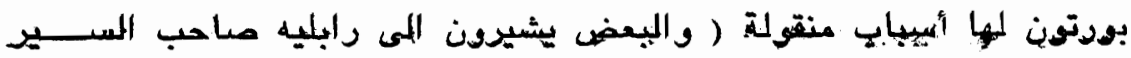

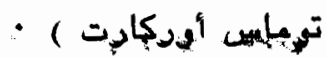

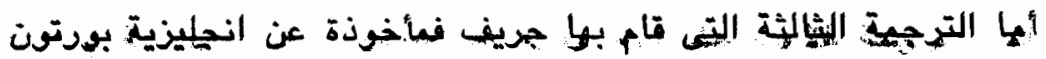

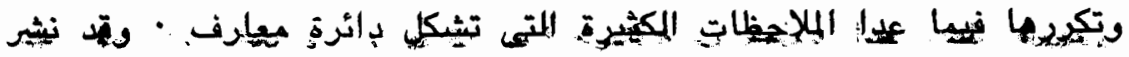

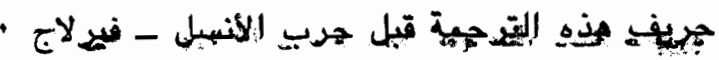

والترجمة الرابعة تأتى لتكمل السابقة • انها مثلها مكونة من ســـتة

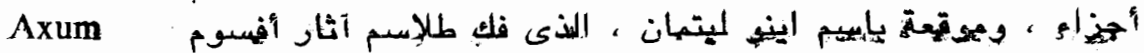

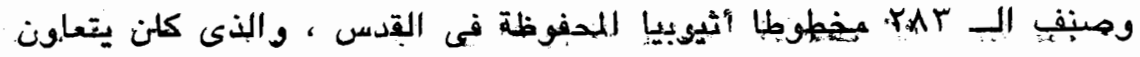

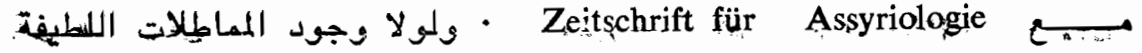
المعروفية عن ترجية بورتون في هذه الترجمة لاعتبرت من أسخى الترجمات

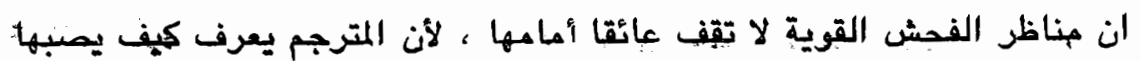

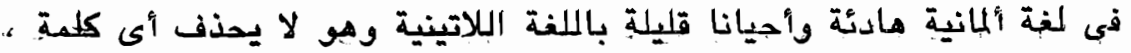

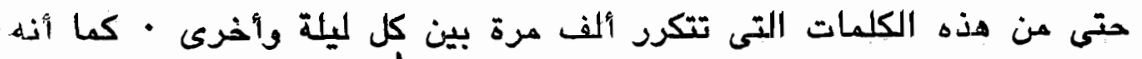

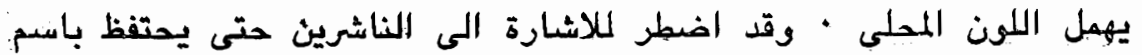

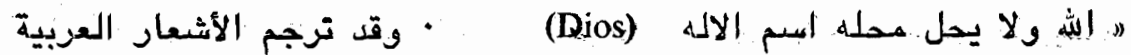

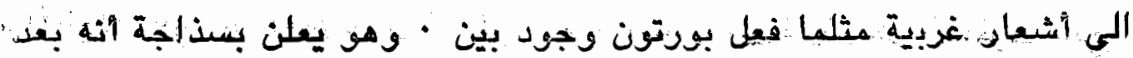

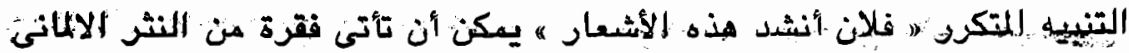

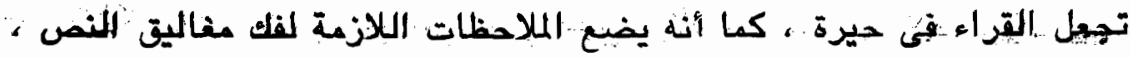

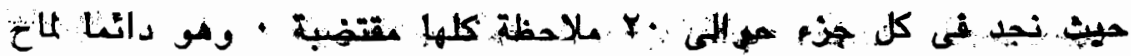




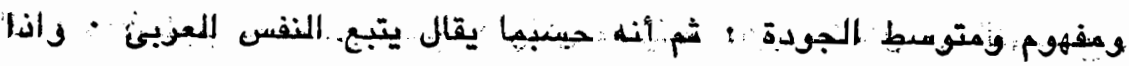

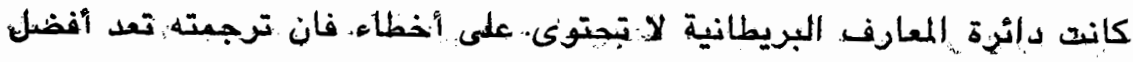

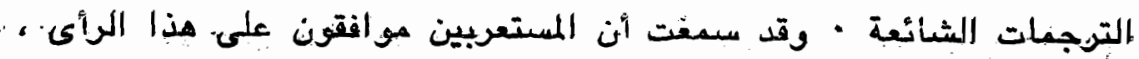

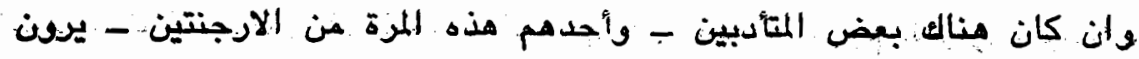
- العيكس

والسبب الذيى أسيتند اليه هو هذا : ان ترجمات بورتون وهارد روس الان

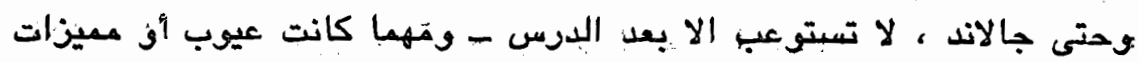

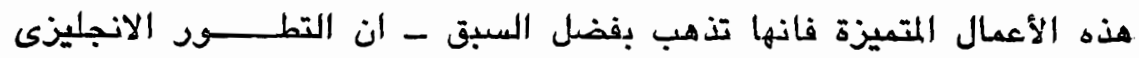

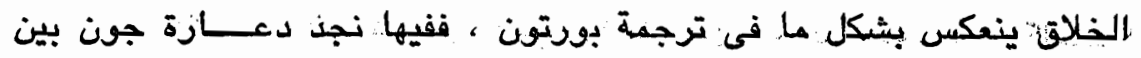

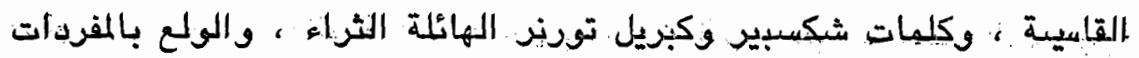

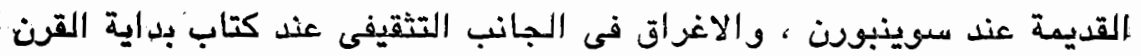

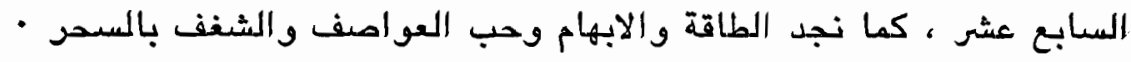

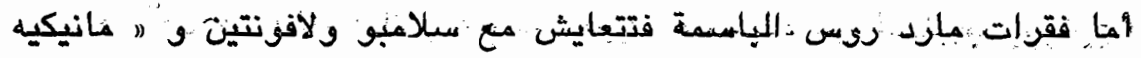

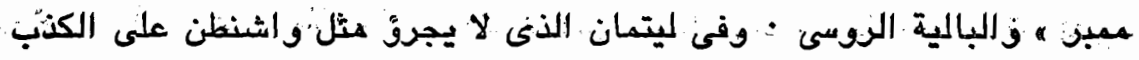

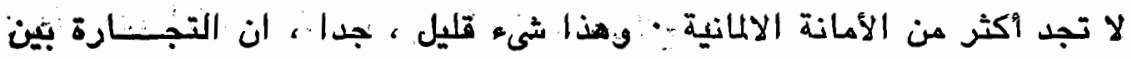

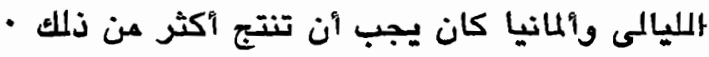

ومعروف أن المانيا فى مجال الفلسفة ، ومجأل القصة قدمت انتاجا

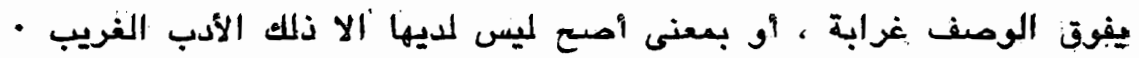

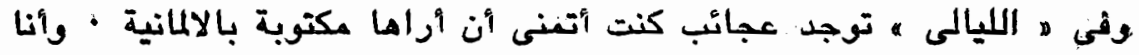

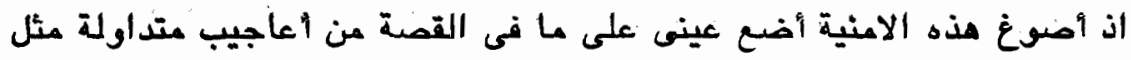

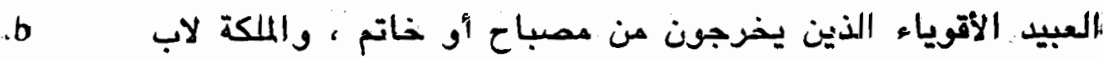

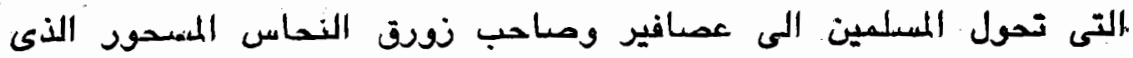
يحمل كلمات مكتوبة على صدره ، فضلا عن الهكايات العامة التى تستلزمها

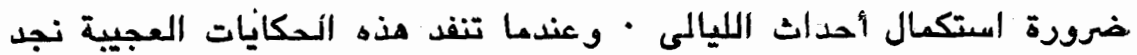

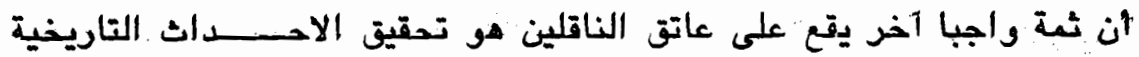

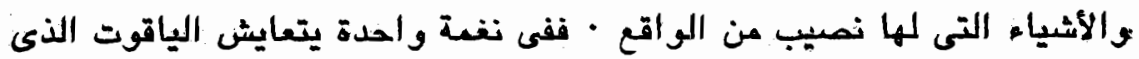

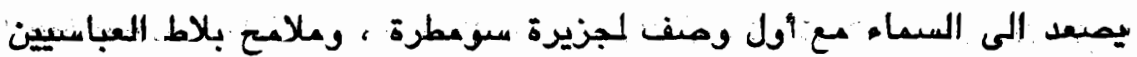

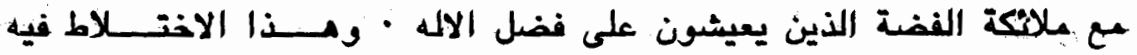

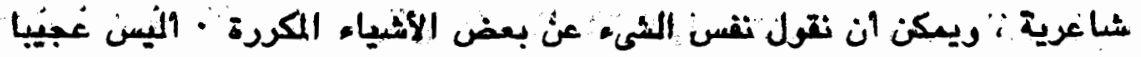


أن نجد الملك شـهريار فى الليلة ب · T بستمع المى قصته نفسها على لمسان الملكة

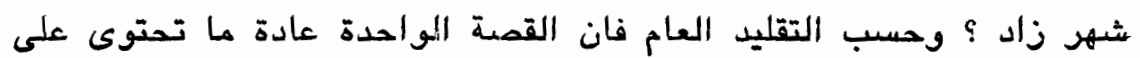

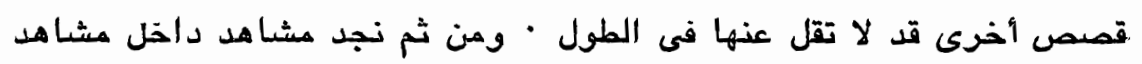

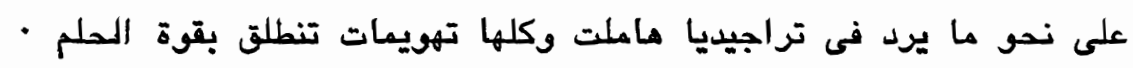

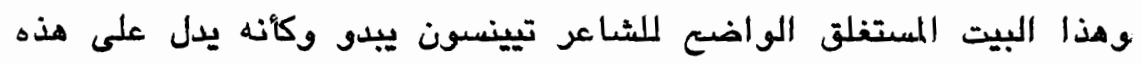

Laborious orient ivory, sphere in sphere Hidra

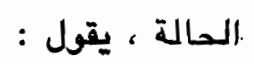

ولمزيد هن الدهشة ، نجد أن هذه الرؤس العرضية عند هيدرا

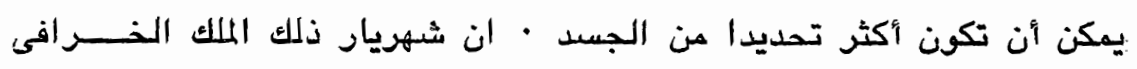

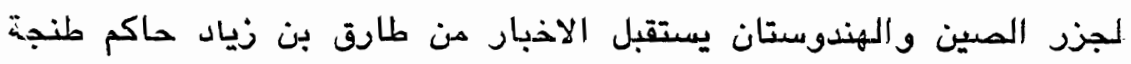

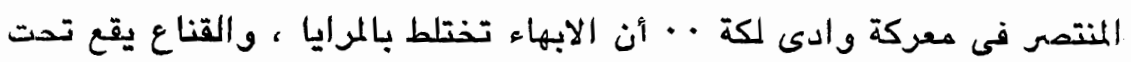

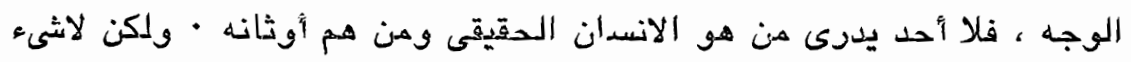

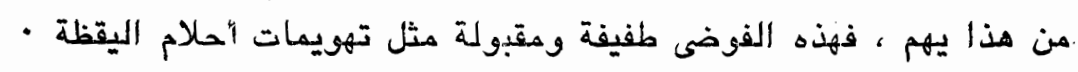

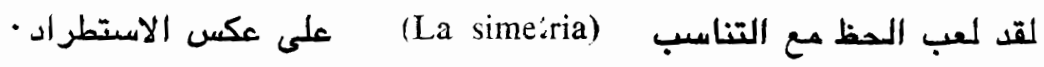

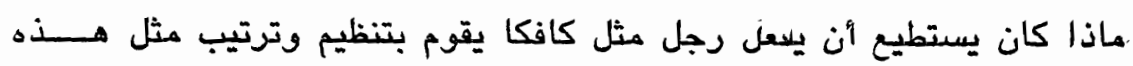

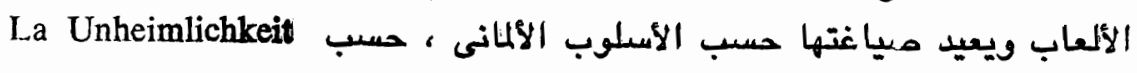


